IZA DP No. 8278

The Shadow Economy and Shadow Labor Force:

A Survey of Recent Developments

Friedrich Schneider

June 2014 


\title{
The Shadow Economy and Shadow Labor Force: A Survey of Recent Developments
}

\author{
Friedrich Schneider \\ Johannes Kepler University of Linz \\ and IZA
}

Discussion Paper No. 8278

June 2014

IZA

P.O. Box 7240

53072 Bonn

Germany

Phone: +49-228-3894-0

Fax: +49-228-3894-180

E-mail: iza@iza.org

\begin{abstract}
Any opinions expressed here are those of the author(s) and not those of IZA. Research published in this series may include views on policy, but the institute itself takes no institutional policy positions. The IZA research network is committed to the IZA Guiding Principles of Research Integrity.

The Institute for the Study of Labor (IZA) in Bonn is a local and virtual international research center and a place of communication between science, politics and business. IZA is an independent nonprofit organization supported by Deutsche Post Foundation. The center is associated with the University of Bonn and offers a stimulating research environment through its international network, workshops and conferences, data service, project support, research visits and doctoral program. IZA engages in (i) original and internationally competitive research in all fields of labor economics, (ii) development of policy concepts, and (iii) dissemination of research results and concepts to the interested public.
\end{abstract}

IZA Discussion Papers often represent preliminary work and are circulated to encourage discussion. Citation of such a paper should account for its provisional character. A revised version may be available directly from the author. 


\section{ABSTRACT}

\section{The Shadow Economy and Shadow Labor Force: A Survey of Recent Developments*}

This survey presents the various methods to estimate the size of the shadow economy, their strengths and weaknesses and the estimation results. The purpose of the survey is threefold. Firstly, it demonstrates that no ideal method to estimate the size and development of the shadow economy exists. Because of its flexibility, the MIMIC method used to get macroestimates of the size of the shadow economy is discussed in greater detail. Secondly, the paper focuses on the definition and causal factors of the shadow economy as well as on a comparison of the size of the shadow economy using different estimation methods. Thirdly, estimations of the size of the shadow economy and shadow labor force are presented and discussed.

JEL Classification: D78, E26, H2, H11, H26, K42, O5, O17

Keywords: $\quad$ shadow economy estimates, shadow labor force, MIMIC approach, methods to estimate the shadow economy, advantages and disadvantages of the measurement methods, shadow labor force and unemployment, micro studies on shadow labor force

Corresponding author:

Friedrich Schneider

Department of Economics

Johannes Kepler University of Linz

Altenbergerstr. 69

4040 Linz

Austria

E-mail: friedrich.schneider@jku.at

\footnotetext{
* A first and different version of this paper was presented at the workshop "Shedding light on the shadow of economy: A critical assessment of methods in tax research", organized by Christoph Kogler, Eva Hofmann and Erich Kirchler, all University of Vienna, Thursday, September 26, and Friday, September 27, 2013.
} 


\section{INTRODUCTION}

Empirical research about the size and development of the shadow economy and shadow labor force all over the world has strongly increased. ${ }^{1)}$ Nowadays, there are so many studies, which use different methods in order to estimate the size and development of the shadow economy, that it is quite difficult to judge the reliability of various methods. Hence, the first goal of this survey is to critically review the various methods estimating the size of the shadow economy and to discuss their strengths and weaknesses. This shall enable an interested reader to realize what advantages and disadvantages the different methods have. A second goal is to present the size of the shadow labor force, which is increasing, and to contrast it to the decreasing size of the shadow economy measured in value-added. A third goal is to present two latest micro studies about the shadow labor force and the relation between the shadow labor force and unemployment.

The survey is structured as follows: In the next section some theoretical considerations are made, starting with a definition of the shadow economy and a brief discussion of its main causes. In section 3 the various measurement methods as well as their strengths and weaknesses are presented. This section also presents estimates of the size of the shadow economy in Germany using different estimation methods. In section 4 estimations of the size of the shadow economy all over the world are presented. In chapter 5 the shadow labor market and shadow labor force are analyzed. The size of the shadow labor market is presented and critically evaluated and some remarks about the shadow labor force and unemployment are made. Finally, section 6 presents a summary and some concluding remarks.

\section{THEORETICAL CONSIDERATIONS}

\subsection{Defining the shadow economy}

Researchers attempting to measure the size of shadow economy face the question of the definition. ${ }^{2)}$ One commonly used working definition is all currently unregistered economic activi-

\footnotetext{
${ }^{1)}$ See e.g. Feld and Schneider (2010), Gerxhani (2003), Schneider (2011), and Schneider and Williams (2013).

2) See Frey and Pommerehne (1984), Thomas (1992), Loayza (1996), Pozo (1996), Lippert and Walker (1997), Schneider (1994a, 1994b, 1997, 1998, 2003, 2005, 2011), Johnson, Kaufmann, and Shleifer (1997), Johnson, Kaufmann and Zoido-Lobatón (1998a), Belev (2003), Gerxhani (2003), and Pedersen (2003). For newer surveys,
} 
ties that would contribute to the officially calculated (or observed) Gross National Product if observed. ${ }^{3)}$ Smith (1994, p. 18) uses the definition "market-based production of goods and services, whether legal or illegal, that escapes detection in the official estimates of GDP." One of the broadest definitions includes "those economic activities and the income derived from them that circumvent government regulation, taxation or observation". 4) As these definitions still leave a lot of questions open, table 2.1 is helpful to demonstrate what could be a reasonable consensus for a definition of the underground (or shadow) economy. From table 2.1 , it is clear that a broad definition of the shadow economy includes unreported income from the production of legal goods and services, either from monetary or barter transactions and so includes all economic activities that would generally be taxable were they reported to the tax authorities.

Table 2.1: A taxonomy of types of underground economic activities

\begin{tabular}{|c|c|c|c|c|}
\hline Type of activity & \multicolumn{2}{|c|}{ Monetary transactions } & \multicolumn{2}{|c|}{ Non-monetary transactions } \\
\hline \multirow[t]{2}{*}{$\begin{array}{l}\text { Illegal Activi- } \\
\text { ties }\end{array}$} & \multicolumn{2}{|c|}{$\begin{array}{l}\text { Trade with stolen goods; drug dealing } \\
\text { and manufacturing; prostitution; } \\
\text { gambling; smuggling; fraud; etc. }\end{array}$} & \multicolumn{2}{|c|}{$\begin{array}{l}\text { Barter of drugs, stolen goods, smug- } \\
\text { gling etc. Produce or growing drugs } \\
\text { for own use. Theft for own use. }\end{array}$} \\
\hline & Tax Evasion & Tax Avoidance & Tax Evasion & Tax Avoidance \\
\hline $\begin{array}{l}\text { Legal Activi- } \\
\text { ties }\end{array}$ & $\begin{array}{l}\text { Unreported in- } \\
\text { come from self- } \\
\text { employment; } \\
\text { Wages, salaries } \\
\text { and assets from } \\
\text { unreported work } \\
\text { related to legal } \\
\text { services and } \\
\text { goods }\end{array}$ & $\begin{array}{l}\text { Employee dis- } \\
\text { counts, fringe } \\
\text { benefits }\end{array}$ & $\begin{array}{l}\text { Barter of legal } \\
\text { services and } \\
\text { goods }\end{array}$ & $\begin{array}{l}\text { All do-it-yourself } \\
\text { work and neigh- } \\
\text { bor help }\end{array}$ \\
\hline
\end{tabular}

Structure of the table is taken from Lippert and Walker (1997, p. 5) with additional remarks

see Schneider and Enste (2000, 2002), Schneider and Williams (2013), Alm, et al. (2004) and Feld and Schneider (2010).

3) This definition is used, for example, by Feige $(1989,1994)$, Schneider $(1994 a, 2003,2005,2011)$, and Frey and Pommerehne (1984). Do-it-yourself activities are not included. For estimates of the shadow economy and do-it-yourself activities for Germany, see Buehn, Karmann and Schneider (2009). This definition is taken from Del'Anno (2003), Del'Anno and Schneider (2004) and Feige (1989). See also Thomas (1999), Fleming, Roman and Farrell (2000).

${ }^{4)}$ This definition is taken from Del'Anno (2003), Del'Anno and Schneider (2004) and Feige (1989). See also Thomas (1999), Fleming, Roman and Farrell (2000). 
This survey uses the following more narrow definition of the shadow economy. ${ }^{5)}$ The shadow economy includes all market-based legal production of goods and services that are deliberately concealed from public authorities for the following reasons:

(1) to avoid payment of taxes, e.g. income taxes or value added taxes,

(2) to avoid payment of social security contributions,

(3) to avoid certain legal labor market standards, such as minimum wages, maximum working hours, safety standards, etc., and

(4) to avoid complying with certain administrative procedures, such as completing statistical questionnaires or other administrative forms.

\subsection{Theorizing about the shadow economy}

A useful starting point for a theoretical discussion of the shadow economy is the pathbreaking study by Allingham and Sandmo (1972) on income tax evasion. While the shadow economy and tax evasion are not congruent, in most cases activities in the shadow economy imply the evasion of direct or indirect taxes, such that the factors determining tax evasion will most certainly also affect the shadow economy. According to Allingham and Sandmo tax compliance depends on its expected costs and benefits. The benefits of tax non-compliance result from the individual marginal tax rate and the true individual income. In the case of the shadow economy the individual marginal tax rate is often roughly calculated using the overall tax burden from indirect and direct taxes including social security contributions. The expected costs of non-compliance derive from deterrence enacted by the state, i.e., the state's auditing activities raising the probability of detection and the fines individuals face when they are caught. Individual morality also plays a role for compliance and additional costs could pertain beyond the tax administration's pure punishment in the form of psychic costs like shame or regret, but also additional pecuniary costs if, for example, a reputation loss results.

Individuals are rational calculators who evaluate the costs and benefits a legal status entails. Their decision to partially or completely participate in the shadow economy is a choice under uncertainty facing a trade-off between the gains if their activities are not discovered and a loss if discovered and penalized. Shadow economic activities $S E$ thus negatively depend on the

\footnotetext{
${ }^{5)}$ Compare also the excellent discussion of the definition of the shadow economy in Pedersen (2003, pp.13-19), who uses a similar definition.
} 
probability of detection $p$ and potential fines $f$, and positively on the opportunity costs of remaining formal denoted as $B$. The opportunity costs are positively determined by the burden of taxation $T$ and high labour costs $W$ - the individual income generated in the shadow economy is usually categorized as labor income rather than capital income - due to labour market regulations. Hence, the higher the tax burden and labor costs, the more incentives individuals have to avoid those costs by working in the shadow economy. The probability of detection $p$ itself depends on enforcement actions $A$ taken by the tax authority and on facilitating activities $F$ accomplished by individuals to reduce detection of shadow economic activities. This discussion suggests the following structural equation:

$$
S E=S E[\bar{p}(\stackrel{+}{A}, \stackrel{-}{F}) ; \bar{f} ; \stackrel{+}{B}(\stackrel{+}{T}, \stackrel{+}{W})] .
$$

Hence, shadow economic activities may be defined as those economic activities and income earned that circumvent government regulation, taxation or observation. More narrowly, the shadow economy includes monetary and non-monetary transaction of legal nature, hence all productive economic activities that would generally be taxable were they reported to the state (tax) authorities. Those activities are deliberately concealed from public authorities to avoid payment of income, value added or other taxes and social security contributions, to avoid compliance with certain legal labor market standards, such as minimum wages, maximum working hours, or safety standards and administrative procedures. The shadow economy thus focuses on productive economic activities that would normally be included in the national accounts but which remain underground due to tax or regulatory burdens. ${ }^{6)}$ Although such legal activities would contribute to the country's value added, they are not captured in the national accounts because they are produced in illicit ways. Informal household economic activities such as do-it-yourself activities and neighborly help are typically excluded in the analysis of the shadow economy.

Kanniainen, Pääkönen and Schneider (2004) incorporate many of these insights in their model of the shadow economy. They hypothesize that tax hikes unambiguously increase the shadow

\footnotetext{
6) Although classical crime activities such as drug dealing are independent of increasing taxes and the causal variables included in the empirical models are only imperfectly linked (or causal) to classical crime activities, the footprints used to indicate shadow economic activities such as currency in circulation also apply for the classic crime. Hence, macroeconomic shadow economy estimates do typically not distinguish legal from illegal underground activities; rather they represent the whole informal economy spectrum.

7) From a social perspective, may even from an economic one, soft forms of illicit employment, such as moonlighting (e.g. construction work in private homes) and its contribution to aggregate value added may be assessed positively. For a discussion of these issues see Thomas (1992) and Buehn, Karmann and Schneider (2009).
} 
economy, while the availability of public goods financed by taxes moderates participation in the shadow economy. The latter effect however depends on the ability to access those public goods. A shortcoming of this analysis is the neglected endogeneity of tax morale and good governance, which is addressed by Feld and Frey (2007) who argue that tax compliance is the result of a complicated interaction between tax morale and deterrence measures. It must be clear to taxpayers what the rules of the game are and as deterrence measures serve as signals for the level of tax morale a society wants to elicit (Posner, 2000), deterrence may also crowd out the intrinsic motivation to pay taxes. Tax morale does not only increase if taxpayers perceive the public goods received in exchange for their tax payments. It may also decrease if individuals perceive political decisions for public activities or the treatment of taxpayers by the tax authorities to be unfair. Tax morale is thus not exogenously given but influenced by deterrence and the quality of state institutions. Table 2.2 presents an overview of the most important determinants influencing the shadow economy. 
Table 2.2: The main causes determining the shadow economy

\begin{tabular}{|c|c|c|}
\hline Causal variable & Theoretical reasoning & References \\
\hline $\begin{array}{l}\text { Tax and Social Se- } \\
\text { curity Contribution } \\
\text { Burdens }\end{array}$ & $\begin{array}{l}\text { The distortion of the overall tax burden affects labor-leisure choices and may } \\
\text { stimulate labor supply in the shadow economy. The bigger the difference be- } \\
\text { tween the total labor cost in the official economy and after-tax earnings (from } \\
\text { work), the greater is the incentive to reduce the tax wedge and to work in the } \\
\text { shadow economy. This tax wedge depends on social security burden/payments } \\
\text { and the overall tax burden, making them to key determinants for the existence } \\
\text { of the shadow economy. }\end{array}$ & $\begin{array}{l}\text { E.g. Thomas (1992), Johnson, } \\
\text { Kaufmann, and Zoido-Lobatón } \\
\text { (1998a,b), Giles (1999a), Tanzi } \\
\text { (1999), Schneider (2003, } \\
\text { 2005), Dell'Anno (2007), } \\
\text { Dell'Anno, Gomez-Antonio } \\
\text { and Alanon Pardo (2007), } \\
\text { Buehn and Schneider (2012) }\end{array}$ \\
\hline $\begin{array}{l}\text { Quality of Institu- } \\
\text { tions }\end{array}$ & $\begin{array}{l}\text { The quality of public institutions is another key factor for the development of } \\
\text { the informal sector. Especially the efficient and discretionary application of } \\
\text { the tax code and regulations by the government plays a crucial role in the de- } \\
\text { cision to work underground, even more important than the actual burden of } \\
\text { taxes and regulations. In particular, a bureaucracy with highly corrupt gov- } \\
\text { ernment officials seems to be associated with larger unofficial activity, while a } \\
\text { good rule of law by securing property rights and contract enforceability in- } \\
\text { creases the benefits of being formal. A certain level of taxation, mostly spent } \\
\text { in productive public services, characterizes efficient policies. In fact, the pro- } \\
\text { duction in the formal sector benefits from a higher provision of productive } \\
\text { public services and is negatively affected by taxation, while the shadow econ- } \\
\text { omy reacts in the opposite way. An informal sector developing as a conse- } \\
\text { quence of the failure of political institutions in promoting an efficient market } \\
\text { economy, and entrepreneurs going underground, as there is an inefficient pub- } \\
\text { lic goods provision, may reduce if institutions can be strengthened and fiscal } \\
\text { policy gets closer to the median voter's preferences. }\end{array}$ & $\begin{array}{l}\text { E.g. Johnson et al. (1998a,b), } \\
\text { Friedman, Johnson, Kaufmann, } \\
\text { and Zoido-Lobaton (2000), } \\
\text { Dreher and Schneider (2009), } \\
\text { Dreher, Kotsogiannis and } \\
\text { McCorriston (2009), Schneider } \\
\text { (2010), Buehn and Schneider } \\
\text { (2012), Teobaldelli (2011), } \\
\text { Teobaldelli and Schneider } \\
\text { (2012), Amendola and } \\
\text { Dell'Anno (2010), Losby et al. } \\
\text { (2002), Schneider and Williams } \\
\text { (2013) }\end{array}$ \\
\hline
\end{tabular}


Table 2.2: The main causes determining the shadow economy (cont.)

\begin{tabular}{|c|c|c|}
\hline Causal variable & Theoretical reasoning & References \\
\hline Regulations & $\begin{array}{l}\text { Regulations, for example labor market regulations or trade barriers, are anoth- } \\
\text { er important factor that reduces the freedom (of choice) for individuals in the } \\
\text { official economy. They lead to a substantial increase in labor costs in the offi- } \\
\text { cial economy and thus provide another incentive to work in the shadow econ- } \\
\text { omy: countries that are more heavily regulated tend to have a higher share of } \\
\text { the shadow economy in total GDP. Especially the enforcement and not the } \\
\text { overall extent of regulation - mostly not enforced - is the key factor for the } \\
\text { burden levied on firms and individuals, making them operate in the shadow } \\
\text { economy. }\end{array}$ & $\begin{array}{l}\text { E.g. Johnson, Kaufmann, and } \\
\text { Shleifer (1997), Johnson, } \\
\text { Kaufmann, and Zoido-Lobatón } \\
\text { (1998b), Friedman, Johnson, } \\
\text { Kaufmann, and Zoido-Lobaton } \\
\text { (2000), Kucera and Roncolato } \\
\text { (2008), Schneider (2011) }\end{array}$ \\
\hline Public Sector Services & $\begin{array}{l}\text { An increase of the shadow economy may lead to fewer state revenues, which in turn } \\
\text { reduce the quality and quantity of publicly provided goods and services. Ultimately, } \\
\text { this may lead to increasing tax rates for firms and individuals, although the deteriora- } \\
\text { tion in the quality of the public goods (such as the public infrastructure) and of the } \\
\text { administration continues. The consequence is an even stronger incentive to partici- } \\
\text { pate in the shadow economy. Countries with higher tax revenues achieved by lower } \\
\text { tax rates, fewer laws and regulations, a better rule of law and lower corruption levels, } \\
\text { should thus have smaller shadow economies. }\end{array}$ & $\begin{array}{l}\text { E.g. Johnson, Kaufmann, and } \\
\text { Zoido-Lobatón (1998a,b), Feld } \\
\text { and Schneider (2010) }\end{array}$ \\
\hline Tax Morale & $\begin{array}{l}\text { The efficiency of the public sector also has an indirect effect on the size of the shad- } \\
\text { ow economy because it affects tax morale. Tax compliance is driven by a psychologi- } \\
\text { cal tax contract that entails rights and obligations from taxpayers and citizens on the } \\
\text { one hand, but also from the state and its tax authorities on the other hand. Taxpayers } \\
\text { are more heavily inclined to pay their taxes honestly if they get valuable public ser- } \\
\text { vices in exchange. However, taxpayers are honest even in cases when the benefit } \\
\text { principle of taxation does not hold, i.e. for redistributive policies, if such political } \\
\text { decisions follow fair procedures. The treatment of taxpayers by the tax authority also } \\
\text { plays a role. If taxpayers are treated like partners in a (tax) contract instead of subor- } \\
\text { dinates in a hierarchical relationship, taxpayers will stick to their obligations of the } \\
\text { psychological tax contract more easily. Hence, (better) tax morale and (stronger) so- } \\
\text { cial norms may reduce the probability of individuals to work underground. }\end{array}$ & $\begin{array}{l}\text { E.g. Feld and Frey (2007), Kirch- } \\
\text { ler (2007), Torgler and Schneider } \\
\text { (2009), Feld and Larsen (2005, } \\
\text { 2009), Feld and Schneider (2010) }\end{array}$ \\
\hline
\end{tabular}


Table 2.2: The main causes determining the shadow economy (cont.)

\begin{tabular}{|c|c|c|}
\hline Causal variable & Theoretical reasoning & References \\
\hline Deterrence & $\begin{array}{l}\text { Despite the strong focus on deterrence in policies fighting the shadow economy and } \\
\text { the unambiguous insights of the traditional economic theory of tax non-compliance, } \\
\text { surprisingly little is known about the effects of deterrence from empirical studies. } \\
\text { This is due to the fact that data on the legal background and the frequency of audits } \\
\text { are not available on an international basis; even for OECD countries such data is dif- } \\
\text { ficult to collect. Either is the legal background quite complicated differentiating fines } \\
\text { and punishment according to the severity of the offense and the true income of the } \\
\text { non-complier, or tax authorities do not reveal how intensively auditing is taking } \\
\text { place. The little empirical survey evidence available demonstrates that fines and pun- } \\
\text { ishment do not exert a negative influence on the shadow economy, while the subjec- } \\
\text { tively perceived risk of detection does. However, the results are often weak and } \\
\text { Granger causality tests show that the size of the shadow economy can impact deter- } \\
\text { rence instead of deterrence reducing the shadow economy. }\end{array}$ & $\begin{array}{l}\text { E.g. Andreoni, Erard and Feinstein } \\
\text { (1998), Pedersen (2003), Feld and } \\
\text { Larsen }(2005,2009) \text {, Feld and } \\
\text { Schneider (2010) }\end{array}$ \\
\hline Agricultural Sector & $\begin{array}{l}\text { The importance of agriculture in the economy is included, since many studies endorse } \\
\text { the idea that informal work is concentrated in highly segmented sectors, with clear } \\
\text { prevalence for the agricultural and related sectors. One of the most important reasons } \\
\text { for this is the minimum enforcement capacity of governments prevalent in rural areas. } \\
\text { The importance of agriculture is measured as the share of agriculture as percentage of } \\
\text { GDP. The larger the agricultural sector, the larger the expected size of the shadow } \\
\text { economy, ceteris paribus. }\end{array}$ & $\begin{array}{l}\text { E.g. Vuletin (2008), De la Roca, } \\
\text { Hernandez, Robles, Torero and } \\
\text { Webber (2002), Greenidge, Hold- } \\
\text { er and Mayers (2005), Mootoo, } \\
\text { Sookram and Watson (2002), } \\
\text { Amendola and Dell'Anno (2010), } \\
\text { Losby et al. (2002) }\end{array}$ \\
\hline $\begin{array}{l}\text { Development of the } \\
\text { official economy }\end{array}$ & $\begin{array}{l}\text { The development of the official economy is another key factor of the shadow econo- } \\
\text { my. The higher (lower) the unemployment quota (GDP-growth), the higher is the } \\
\text { incentive to work in the shadow economy, ceteris paribus. }\end{array}$ & $\begin{array}{l}\text { Schneider and Williams (2013) } \\
\text { Feld and Schneider (2010) }\end{array}$ \\
\hline Self-employment & $\begin{array}{l}\text { The higher self-employment is, the more activities can be done in the shadow econo- } \\
\text { my, ceteris paribus. }\end{array}$ & $\begin{array}{l}\text { Schneider and Williams (2013) } \\
\text { Feld and Schneider (2010) }\end{array}$ \\
\hline
\end{tabular}




\section{METHODS TO ESTIMATE THE SIZE OF THE SHADOW ECON- OMY}

Estimating the size of a shadow economy is a difficult and challenging task. In this chapter I give a short but comprehensive overview on the various procedures for estimating the size of a shadow economy. Three different categories of measurement methods are most widely used, and each is briefly discussed.

\subsection{Direct approaches}

These are microeconomic approaches that employ either well designed surveys and samples based on voluntary replies or tax auditing and other compliance methods. Sample surveys designed to estimate the shadow economy are widely used ${ }^{8)}$. The main disadvantages of this method are the flaws of all surveys. For example, the average precision and results depend greatly on the respondent's willingness to cooperate, it is difficult to assess the amount of undeclared work from a direct questionnaire, most interviewers hesitate to confess to fraudulent behavior, and responses are of uncertain reliability, which makes it difficult to calculate a true estimate (in monetary terms) of the extend of undeclared work. The main advantage of this method lies in the detailed information about the structure of the shadow economy but the results from these kinds of surveys are very sensitive to the way the questionnaire is formulat$\mathrm{ed}^{9)}$.

Estimates of the shadow economy can also be based on the discrepancy between income declared for tax purposes and that measured by selective checks. Fiscal auditing programs have been particularly effective in this regard. Since these programs are designed to measure the amount of undeclared taxable income, they may also be used to calculate the size of the shadow economy. ${ }^{10)}$ However, a number of difficulties beset this approach. First, using tax compliance data is equivalent to using a (possibly biased) sample of the population. In general, the

\footnotetext{
${ }^{8)}$ The direct method of voluntary sample surveys has been extensively used for Norway by Isachsen et al. (1982), and Isachsen and Strom (1985). For Denmark this method is used by Mogensen et. al. (1995) in which they report „estimates“ of the shadow economy of $2.7 \%$ of GDP for 1989, of $4.2 \%$ of GDP for 1991, of 3.0\% of GDP for 1993 and of 3.1\% of GDP for 1994. In Pedersen (2003) estimates of the Danish shadow economy contain the years 1995 with $3.1 \%$ up to 2001 with 3.8\%. See also newer studies like Feld and Larsen $(2005,2008$, 2009) which reach similar sizes of the shadow economy for Germany.

${ }^{9)}$ The advantages and disadvantages of this method are extensively dealt by Pedersen (2003), Mogensen (1985) and Mogensen et. al (1995) in their excellent and very carefully done investigations.

${ }^{10)}$ In the United States, IRS (1979, 1983), Simon and Witte (1982), Witte (1987), Clotefelter (1983), and Feige (1986). For a more detailed discussion, see Dallago (1990) and Thomas (1992).
} 
selection of taxpayers for tax audits is not random but based on properties of submitted (tax) returns that indicate a certain likelihood of tax fraud. Consequently, such a sample is not a random one of the whole population, and estimates of the shadow economy based upon a biased sample may not be accurate. Second, estimates based on tax audits reflect only that portion of the shadow economy income authorities discover, and this is likely to be only a fraction of all hidden income.

Survey results can also be inconsistent internationally. In addition to the studies by Feld and Larsen (2005, 2008, 2009), Haigner et al. (2013), and Enste and Schneider (2006) for Germany, survey methods have been applied in the Northern countries and Great Britain (Isachsen and Strøm (1985), Pedersen (2003)) as well as in the Netherlands (Van Eck and Kazemier (1988), Kazemier (2006). The questionnaires underlying these studies are broadly comparable in design; however, recent attempts by the European Union to provide survey results for all member states have run into great difficulties of comparability (Renooy et al. (2004), European Commission (2007)). The wording of the questionnaires becomes more and more cumbersome, depending on the culture of different countries with respect to the underground economy.

A further disadvantage of these two direct methods (surveys and tax auditing) is the point estimate character. In general, they capture shadow economic activities only partially and may be seen as lower bound estimates. Going back to the definition of the shadow economy, this method captures mostly the amount of shadow labor activities in households and rarely in or between firms and it does not provide value added figures. However, they have one considerable advantage: they provide detailed information about shadow economy activities, the structure and composition of the activities as well as the socio-economic characteristics and motives of those who work in the shadow economy.

To summarize:

Survey methods are likely to underestimate the shadow economy because people are likely to under-declare in surveys what they are trying to hide from authorities. In order to minimize the number of respondents dishonestly replying or totally declining answers to sensitive questions, structured interviews are undertaken (usually face to face), in which respondents slowly become accustomed to the main purpose of the survey. The first part of the questionnaire aims at shaping respondents' perceptions of the issue's intended. The second part asks questions 
about the respondents' activities in the shadow economy. A third part contains the usual socio-demographic questions. Nevertheless, the results of the shadow economy estimates from survey methods are clearly lower-bound estimated compared to other approaches.

\subsection{Indirect approaches}

These approaches, which are also called indicator approaches, are mostly macroeconomic and use various economic and other indicators that contain information about the development of the shadow economy (over time). Relating them to the definition of the shadow economy, they provide value added figures, in most cases the quite often legally bought material is included; hence, they are upper bound estimates with the danger of a double counting problem due to the inclusion of the legally bought material. Currently there are five indicators that leave some traces of the shadow economy.

\subsubsection{The discrepancy between national expenditure and income statistics}

This approach is based on discrepancies between income and expenditure statistics. In national accounting the income measure of GNP should be equal to the expenditure measure of GNP. Thus, if an independent estimate of the expenditure site of the national accounts is available, the gap between the expenditure measure and the income measure can be used as an indicator of the extent of the shadow economy. ${ }^{11)}$ Since national accounts statisticians are anxious to minimize this discrepancy, the initial discrepancy or first estimate, rather than the published discrepancy, should be employed as an estimate of the shadow economy. If all the components of the expenditure side are measured without error, then this approach would indeed yield a good estimate of the size of the shadow economy. Unfortunately, however, this is not the case. Instead, the discrepancy reflects all omissions and errors everywhere in the

\footnotetext{
${ }^{11)}$ See, e.g., Franz (1983) for Austria; MacAfee (1980) O'Higgins (1989) and Smith (1985), for Great Britain; Petersen (1982) and Del Boca (1981) for Germany; Park (1979) for the United States. For a critical survey, see Thomas (1992).
} 
national accounts statistics as well as shadow economy. These estimates may therefore be crude and of questionable reliability. ${ }^{12)}$

\subsubsection{The discrepancy between the official and actual labor force}

A decline in participation of the labor force in the official economy can be seen as an indication of increased activity in the shadow economy. If total labor force participation is assumed to be constant, then a decreasing official rate of participation can be seen as an indicator of an increase of shadow economic activities, ceteris paribus. ${ }^{13)}$ One weakness of this method is that differences in the rate of participation may also have other causes. Also, people can work in the shadow economy and have a job in the official economy. Therefore such estimates may be viewed as weak indicators of the size and development of the shadow economy.

\subsubsection{The transactions approach}

This approach has been fully developed by Feige. ${ }^{14)}$ It is based upon the assumption that there is a constant relation over time between the volume of transaction and official GNP, as summarized by the well-known Fisher quantity equation, or $M * V=p^{*} T$ (with $M$ money, $V$ velocity, $p$ prices, and $T$ total transactions). Assumptions also have to be made about the velocity of money and about the relationships between the value of total transactions $p * T$ and total (official + unofficial) nominal GNP. Relating total nominal GNP to total transactions, the GNP of the shadow economy can be calculated by subtracting the official GNP from total nominal GNP.

However, to derive figures for the shadow economy, one must also assume a base year in which there is no shadow economy and therefore the ratio of $p * T$ to total nominal (official $=$ total) GNP was "normal" and would have been constant over time if there had been no shadow economy. To obtain reliable shadow economy estimates, precise figures of the total vol-

\footnotetext{
12) A related approach is pursued by Pissarides and Weber (1989), who use micro data from household budget surveys to estimate the extent of income understatement by self-employed.

13) Such studies have been made for Italy, see e.g., Contini (1981) and Del Boca (1981); for the United States, see O’Neill (1983), for more recent studies, see Williams (2009, 2013), Williams and Lansky (2013), and Williams and Rodgers (2013), for a critical survey, see again Thomas (1992).

${ }^{14)}$ For an extended description of this approach, see Feige (1996); for a further application for the Netherlands, Boeschoten and Fase (1984), and for Germany, Langfeldt (1984).
} 
ume of transactions should be available, which might be especially difficult for cash transactions, because they depend, among other factors, on the durability of bank notes in terms of the quality of the papers on which they are printed. ${ }^{15)}$ Also, the assumption is made that all variations in the ratio between the total value of transaction and the officially measured GNP are due to the shadow economy. This means that a considerable amount of data is required in order to eliminate financial transactions from "pure" cross payments, which are legal and have nothing to do with the shadow economy. In general, although this approach is theoretically attractive, the empirical requirements necessary to obtain reliable estimates are so difficult to fulfill that its application can lead to doubtful results.

\subsubsection{The currency demand approach}

The currency demand approach was first used by Cagan (1958), who considered the correlation between currency demand and tax pressure (as one cause of the shadow economy) for the United States over the period 1919 to 1955. 20 years later, Gutmann (1977) used the same approach but without any statistical procedures. Cagan's approach was further developed by Tanzi (1980, 1983), who estimated a currency demand function for the United States for the period 1929 to 1980 in order to calculate the size of the shadow economy. His approach assumes that shadow (or hidden) transactions are undertaken in the form of cash payments, so as to leave no observable traces for the authorities. An increase in the size of the shadow economy will therefore increase the demand for currency. To isolate the resulting excess demand for currency, an equation for currency demand is estimated over time. All conventional possible factors, such as the development of income, payment habits, interest rates, credit and other debt cards as a substitute for cash and so on, are controlled for. Additionally, such variables as the direct and indirect tax burden, government regulation, state institutions and tax morale, which are assumed to be the major factors causing people to work in the shadow economy, are included in the estimation equation. The basic regression equation for the currency demand, proposed by Tanzi (1983), is the following:

$$
\ln \left(C / M_{2}\right)_{t}=\beta_{O}+\beta_{1} \ln (1+T W)_{t}+\beta_{2} \ln (W S / Y)_{t}+\beta_{3} \ln R_{t}+\beta_{4} \ln (Y / N)_{t}+u_{t}
$$

with $\beta_{1}>0, \beta_{2}>0, \beta_{3}<0, \beta_{4}>0$, where $\ln$ denotes natural logarithms, $C / M_{2}$ is the ratio of cash holdings to current and deposit accounts, $T W$ is a weighted average tax rate (to proxy

\footnotetext{
${ }^{15)}$ For a detailed criticism of the transaction approach see Boeschoten and Fase (1984), Frey and Pommerehne (1984), Kirchgaessner (1984), Tanzi (1982a,b, 1986), Dallago (1990), Thomas (1986, 1992, 1999) and Giles (1999a).
} 
changes in the size of the shadow economy), $W S / Y$ is a proportion of wages and salaries in national income (to capture changing payment and money holding patterns), $R$ is the interest paid on savings deposits (to capture the opportunity cost of holding cash) and $Y / N$ is the per capita income. ${ }^{16)}$ Any "excess" increase in currency, or the amount unexplained by conventional or normal factors is then attributed to the rising tax burden and other reasons leading people to work in the shadow economy. Figures for the size and development of the shadow economy can be calculated in a first step by comparing the difference between the development of currency when the direct and indirect tax burden and government regulation are held at lowest values, and the development of currency with the current (higher) burden of taxation and government regulation. Assuming in a second step the same income velocity for currency used in the shadow economy as for legal MI in the official economy, the size of the shadow can be computed and compared to the official GDP.

This is one of the most commonly used approaches. It has been applied to many countries ${ }^{17)}$ all over the world but has nevertheless been criticized on various grounds. ${ }^{18)}$ The most commonly raised objections to this method are:

(1) Not all transactions in the shadow economy are paid in cash. Isachsen and Strom (1985) used the survey method to find out that in Norway, in 1980, roughly 80 percent of all transactions in the hidden sector were paid in cash. The size of the total shadow economy (including barter) may thus be even larger than previously estimated.

(2) Most studies consider only one particular factor, the tax burden, as a cause of the shadow economy. But others (such as the impact of regulation, taxpayers' attitudes toward the state, tax morality and so on) are not considered, because for most countries reliable data is not available. If, as seems likely, these other factors also have an impact on the extent of the hidden economy, it might again be higher than reported in most studies. ${ }^{19)}$

\footnotetext{
16) The estimation of such a currency demand equation has been criticized by Thomas (1999) but part of this criticism has been considered by the work of Giles (1999a,b) and Bhattacharyya (1999), who both use the latest econometric technics.

${ }^{17)}$ See Karmann (1986, 1990), Schneider (1997, 1998, 2011), Johnson et al. (1998a), Williams and Windebank (1995), and Schneider and Williams (2013).

18) See Thomas (1992, 1999), Feige (1986), Pozo (1996), Pedersen (2003), Ahumada et al. (2004), Schneider (2011), and Schneider and Williams (2013).

${ }^{19)}$ One (weak) justification for the only use of the tax variable is that this variable has by far the strongest impact on the size of the shadow economy in the studies known to the authors. The only exception is the study by Frey and Weck-Hannemann (1984) where the variable "tax immorality" has a quantitatively larger and statistically stronger influence than the direct tax share in the model approach. In the study of Pommerehne and Schneider
} 
(3) As discussed by Garcia (1978), Park (1979), and Feige (1996), increases in currency demand deposits are largely due to a slowdown in demand deposits rather than to an increase in currency caused by activities in the shadow economy, at least in the case of the United States.

(4) Blades (1982) and Feige $(1986,1996)$ criticize Tanzi's studies on the grounds that the US dollar is used as an international currency so that Tanzi should have considered (and controlled for) the presence of US dollars, which are used as an international currency and held in cash abroad. ${ }^{20)}$ Frey and Pommerehne (1984) and Thomas (1986, 1992, 1999) claim that Tanzi's parameter estimates are not very stable. ${ }^{21)}$

(5) Most studies assume the same velocity of money in official and shadow economies. As argued by Hill and Kabir (1996) for Canada and by Klovland (1984) for the Scandinavian countries, there is considerable uncertainty about the velocity of money in the official economy, and the velocity of money in the hidden sector is even more difficult to estimate. Without knowledge about the velocity of currency in the shadow economy, one has to accept the assumption of an equal velocity of money in both sectors.

(6) Ahumada, Alvaredo, Canavese, and Canavese (2004) show that the currency approach together with the assumption of equal income velocity of money in the reported and the hidden transaction is only correct if the income elasticity is 1 .

(7) Finally, the assumption of no shadow economy in a base year is open to criticism. Relaxing this assumption would again imply an upward adjustment of the size of the shadow economy.

\footnotetext{
(1985), for the U.S., besides various tax measures, data for regulation, tax immorality, minimum wage rates are available, the tax variable has a dominating influence and contributes roughly $60-70 \%$ to the size of the shadow economy. See also Zilberfarb (1986).

${ }^{20)}$ Another study by Tanzi (1982a, esp. pp. 110-113) explicitly deals with this criticism. A very careful investigation of the amount of US dollars used abroad and US currency used in the shadow economy and for "classical" crime activities has been undertaken by Rogoff (1998), who concludes that large denomination bills are major driving force for the growth of the shadow economy and classical crime activities, due largely to reduced transactions costs.

${ }^{21)}$ However in studies for European countries Kirchgässner $(1983,1984)$ and Schneider (1986) conclude that the estimation results for Germany, Denmark, Norway and Sweden are quite robust when using the currency demand method. Hill and Kabir (1996) find for Canada that the rise of the shadow economy varies with respect to the tax variable used; they conclude "when the theoretically best tax rates are selected and a range of plausible velocity values is used, this method estimates underground economic growth between 1964 and 1995 at between $3 \%$ and $11 \%$ of GDP.” (p.1553).
} 


\subsubsection{The physical input (electricity consumption) method}

\subsubsection{The Kaufmann - Kaliberda Method ${ }^{22)}$}

To measure overall (official and unofficial) economic activity in an economy, Kaufmann and Kaliberda (1996) assume that electric-power consumption is regarded as the single best physical indicator of overall (or official plus unofficial) economic activity. Overall economic activity and electricity consumption have been empirically observed throughout the world to move in lockstep with an electricity to GDP elasticity usually close to one. This means that the growth of total electricity consumption is an indicator for growth of overall (official and unofficial) GDP. By having this proxy measurement for the overall economy and then subtracting from this overall measure the estimates of official GDP, Kaufmann and Kaliberda (1996) derive an estimate of unofficial GDP. This method is very simple and appealing. However, it can also be criticized on various grounds:

(1) Not all shadow economy activities require a considerable amount of electricity (e.g. personal services), and other energy sources can be used (gas, oil, coal, etc.). Only a part of the shadow economy will be indicated.

(2) Over time, there has been considerable technical progress so that both the production and use of electricity are more efficient than in the past, and this will apply in both official and unofficial uses.

(3) There may be considerable differences or changes in the elasticity of electricity/GDP across countries and over time. ${ }^{23)}$

\subsubsection{The Lackó method}

Lackó $(1998,1999,2000 a, b)$ assumes that a certain part of the shadow economy is associated with the household consumption of electricity. This part comprises the so-called household production, do-it-yourself activities, and other non-registered production and services. Lackó further assumes that in countries where the portion of the shadow economy associated with the household electricity consumption is high, the rest of the hidden economy (or the part Lackó cannot measure) will also be high. Lackó (1996, pp.19 ff.) assumes that in each coun-

\footnotetext{
${ }^{22)}$ This method was used earlier by Lizzeri (1979), Del Boca and Forte (1982), and then was used much later by Portes (1996), Kaufmann and Kaliberda (1996), Johnson et al. (1997). For a critique see Lackó (1998).

23) Johnson et al. (1997) make an attempt to adjust for changes in the elasticity of electricity/GDP.
} 
try a part of the household consumption of electricity is used in the shadow economy. Lackó's approach (1998, p.133) can be described by the following two equations:

$\ln E_{i}=\alpha_{1} \ln C_{i}+\alpha_{2} \ln P R_{i}+\alpha_{3} G_{i}+\alpha_{4} Q_{i}+\alpha_{5} H_{i}+u_{i}$, with $\alpha_{1}>0, \alpha_{2}<0, \alpha_{3}>0, \alpha_{4}$

$<0, \alpha_{5}>0$ and

$H_{i}=\beta_{1} T_{i}+\beta_{2}\left(S_{i}-T_{i}\right)+\beta_{3} D_{i}$ with $\beta_{1}>0, \beta_{2}<0, \beta_{3}>0$

where $i$ indicates the number assigned to the country,

$E_{i}$ is per capita household electricity consumption in country $i$,

$C_{i}$ is per capita real consumption of households without the consumption of electricity in country $\mathrm{i}$ in US dollars (at purchasing power parity),

$P R_{i}$ is the real price of consumption of $1 \mathrm{kWh}$ of residential electricity in US dollars (at purchasing power parity),

$G_{i}$ is the relative frequency of months with the need of heating in houses in country $i$,

$Q_{i}$ is the ratio of energy sources other than electricity energy to all energy sources in household energy consumption,

$H_{i}$ is the per capita output of the hidden economy,

$T_{i}$ is the ratio of the sum of paid personal income, corporate profit and taxes on goods and services to GDP,

$S_{i}$ is the ratio of public social welfare expenditures to GDP, and

$D_{i}$ is the sum on number of dependants over 14 years and of inactive earners, both per 100 active earners.

In a cross country study, she estimates the first equation substituting for $H_{i}$ with the second equation. For the calculation of the actual size (value added) of the shadow economy, Lackó further must know how much GDP is produced by one unit of electricity in the shadow economy of each country. Since these data are not known, she takes the result of one of the known shadow economy estimates calculated for a market economy with another approach for the early 1990s, and applies this to the other countries. Lackó used the shadow economy of the United States as such a base (the shadow economy value of $10.5 \%$ of GDP taken from Morris (1993)) and calculated the size of the shadow economy for other countries. Lackó's method is also open to criticism:

(1) Not all shadow economy activities require a considerable amount of electricity and other energy sources can be used. 
(2) Shadow economy activities do not take place only in the household sector.

(3) It is doubtful whether the ratio of social welfare expenditures can be used as the explanatory factor for the shadow economy, especially in transition and developing countries.

(4) It is questionable, which is the most reliable base value of the shadow economy in order to calculate the size of the shadow economy for all other countries, especially for the transition and developing countries.

\subsubsection{The model approach ${ }^{24)}$}

\subsubsection{General remarks}

All methods described so far consider just one indicator that to capture all effects of the shadow economy. However, shadow economy effects show up simultaneously in the production, labor, and money markets. An even more important critique is that the causes that determine the size of the shadow economy are taken into account only in some of the monetary approach studies that usually consider one cause, the burden of taxation. The model approach explicitly considers multiple causes of the existence and growth of the shadow economy ${ }^{25)}$, as well as the multiple effects of the shadow economy over time. The empirical method used is quite different from those used so far. It is based on the statistical theory of unobserved variables, which considers multiple causes and multiple indicators of the phenomenon to be measured.

As the size of the shadow economy is an unknown (hidden) figure, a latent estimator approach using the MIMIC (i.e. multiple indicators, multiple causes estimation) procedure is applied. This method is based on the statistical theory of unobserved variables. The statistical idea behind such a model is to compare a sample covariance matrix, that is, a covariance matrix of observable variables, with the parametric structure imposed on this matrix by a hypothesized model. ${ }^{26)}$ Using covariance information among the observable variables, the unob-

\footnotetext{
${ }^{24)}$ See also Aigner et al. (1988, p. 303), applying this approach for the United States over time; for Germany this approach has been applied by Karmann $(1986,1990)$. The pioneers of this approach are Weck (1983), Frey and Weck-Hannemann (1984), who applied this approach to cross-section data from the 24 OECD countries for various years. Before turning to this approach they developed the concept of ,soft modeling“ (Frey et al. (1982), Frey and Weck (1983a,b)), an approach which has been used to provide a ranking of the relative size of the shadow economy in different countries. One paper dealing extensively with the MIMIC approach, its development and its weaknesses is from Del'Anno (2003) as well as the excellent study by Giles and Tedds (2002).

25) Thomas (1992); Schneider (2003, 2005, 2011); Pozo (1996); Johnson et al. (1998a,b); Giles (1997a,b, 1999a,b,c); Giles and Tedds (2002), Giles et al. (2002), Del'Anno (2003) and Del'Anno and Schneider (2004).

26) Estimation of a MIMIC model with a latent variable can be done by means of a computer program for the analysis of covariance structures, such as LISREL (Linear Structural Relations). A useful overview of the LISREL software package in an economics journal is Cziraky (2004).
} 
servable variable is in the first step linked to observable variables in a factor analytical model also called measurement model. Second, the relationships between the unobservable variable and observable variables are specified through a structural model. Therefore, a MIMIC model is the simultaneous specification of a factor and a structural model. In this sense, the MIMIC model tests the consistency of a 'structural' theory through data and is thus a confirmatory, rather than an exploratory technique. An economic theory is thus tested examining the consistency of actual data with the hypothesized relationships between the unobservable (latent) variable or factor and the observable (measurable) variables. ${ }^{27)}$ In general, a confirmatory factor analysis has two goals: (i) to estimate parameters such as coefficients and variances; and (ii) to assess the fit of the model. For the analysis of shadow economy activities these two goals mean (i) to estimate the relationships between a set of observable variables, divided into causes and indicators, and the shadow economy activity (unobservable variable); and (ii) to test if the researcher's theory or the derived hypotheses as a whole fit the data. MIMIC models are, compared to regression models, a rarely used method by economists, which might be due to an under-evaluation of their capabilities with respect to their potential contribution to economic research.

\subsubsection{A detailed description of the MIMIC model}

The idea of the MIMIC model application is to examine the relationships between the latent variable size of shadow economy activities and observable variables in terms of the relationships among a set of observable variables by using their covariance information. The observable variables are divided into causes and indicators of the latent variable (see figure 3.1). The key benefits of the MIMIC model are that it allows modelling shadow economy activities as an unobservable (latent) variable and that it takes into account its multiple determinants (causes) and multiple effects (indicators). A factor- analytic approach is used to measure the size of shadow economy activities as an unobserved variable over time. The unknown coefficients are estimated in a set of structural equations, as the 'unobserved' variable, that is, the size of the shadow economy cannot be measured directly. Formally, the MIMIC model consists of two parts: the structural equation model and the measurement model.

\footnotetext{
27) On the contrary, in an exploratory factor analysis a model is not specified in advance, i.e., beyond the specification of the number of latent variables (factors) and observed variables the researcher does not specify any structure of the model. This means that one assumes that all factors are correlated, all observable variables are directly influenced by all factors, and all measurement errors are uncorrelated with each other. In practice, however, the distinction between a confirmatory and an exploratory factor analysis is less strong. Facing poorly fitting models, researchers using the MIMIC model often modify their models in an exploratory way in order to improve the fit. Thus, most applications fall between the two extreme cases of exploratory (non- specified model structure) and confirmatory (ex- ante specified model structure) factor analysis (Long 1983a, pp. 11-17).
} 


\section{Figure 3.1: The MIMIC model}

\section{Causes}

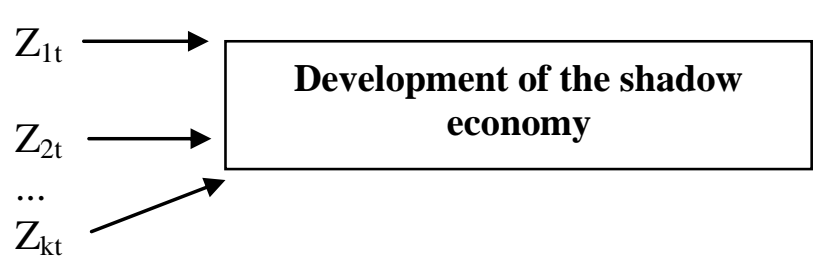

INDICATORS

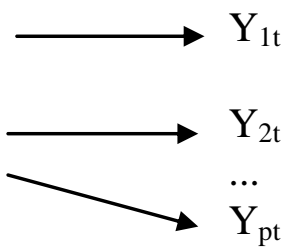

In the measurement model, the unobservable variable $\eta_{t}$ determines a $p$ vector $y_{t}^{\prime}=\left(y_{1 t}, y_{2 t}, \ldots, y_{p t}\right)^{\prime}$ of indicators, that is, observable variables that reflect the shadow economy activities, subject to a $p$ vector of random error terms $\varepsilon^{\prime}{ }_{t}=\left(\varepsilon_{1 t}, \varepsilon_{2 t}, \ldots, \varepsilon_{p t}\right)^{\prime}$. The unobservable variable $\eta_{t}$ is a scalar and $\lambda$ is a $p$ column vector of parameters that relates $\boldsymbol{y}_{t}$ to $\eta_{t}$. The measurement equation is given by:

$$
y_{t}=\lambda \eta_{t}+\varepsilon_{t}
$$

The structural model determines the unobservable variable $\eta_{t}$ by a set of exogenous causes $x^{\prime}{ }_{t}=\left(x_{1 t}, x_{2 t}, \ldots, x_{q t}\right)^{\prime}$ that may be useful in predicting its movement and size, subject to a structural disturbance error term $\varsigma_{t}$. The structural equation is given by:

$$
\eta_{t}=\gamma^{\prime} x_{t}+\varsigma_{t}
$$

where $\gamma^{\prime}$ is a $q$ row vector of structural parameters. ${ }^{28)}$ In equations (2) and (3) it is assumed that $\zeta_{t}$ and the elements of $\varepsilon_{t}$ are normally, independently and identically distributed, the variance of the structural disturbance term $\varsigma_{t}$ is denoted by $\psi$, and $\boldsymbol{\Theta}_{\varepsilon}=\mathrm{E}\left(\boldsymbol{\varepsilon}_{\boldsymbol{t}} \boldsymbol{\varepsilon}_{\boldsymbol{t}}{ }^{\prime}\right)$ is the $(p \times p)$ covariance matrix of the measurement errors. ${ }^{29)}$ Figure 3.1 shows the path diagram of the MIMIC model.

The MIMIC model of shadow economy activities estimated in this paper uses three indicators and nine causes. Hence, within this model, equations (2) and (3) are specified as follows:

\footnotetext{
${ }^{28)}$ Without loss of generality, all variables are taken as standardized deviations from their means.

${ }^{29)}$ In the standard MIMIC model the measurement errors are assumed to be independent of each other, but this restriction could be relaxed (Stapleton 1978, p. 53).
} 


$$
\begin{aligned}
& {\left[\begin{array}{l}
y_{1 t} \\
y_{2 t} \\
y_{3 t}
\end{array}\right]=\left[\begin{array}{l}
\lambda_{1} \\
\lambda_{2} \\
\lambda_{3}
\end{array}\right] \cdot \eta_{t}+\left[\begin{array}{l}
\varepsilon_{1 t} \\
\varepsilon_{2 t} \\
\varepsilon_{3 t}
\end{array}\right]} \\
& \eta_{t}=\left[\begin{array}{lllllllll}
\gamma_{1} & \gamma_{2} & \gamma_{3} & \gamma_{4} & \gamma_{5} & \gamma_{6} & \gamma_{7} & \gamma_{8} & \gamma_{9}
\end{array}\right] \cdot\left[\begin{array}{l}
\boldsymbol{X}_{1 t} \\
\boldsymbol{X}_{2 t} \\
\boldsymbol{X}_{3 t} \\
\boldsymbol{X}_{4 t} \\
\boldsymbol{X}_{5 t} \\
\boldsymbol{X}_{6 t} \\
\boldsymbol{X}_{7 t} \\
\boldsymbol{X}_{8 t} \\
\boldsymbol{X}_{9 t}
\end{array}\right]+\zeta_{t}
\end{aligned}
$$

Substituting (2) into (3) yields a reduced form equation which expresses the relationships between the observed causes and indicators, that is, between $\boldsymbol{x}_{\boldsymbol{t}}$ and $\boldsymbol{y}_{\boldsymbol{t}}$. This is shown in equation (6):

$$
y_{t}=\Pi x_{t}+z_{t}
$$

where: $\boldsymbol{\Pi}=\lambda y^{\prime}$ is a $\left(\begin{array}{ll}3 & 9\end{array}\right)$ reduced form coefficient matrix and $z_{t}=\lambda \varsigma_{t}+\varepsilon_{t}$ is a reduced form vector of a linear transformation of disturbances that has a $(3 \times 3)$ reduced form covariance matrix $\boldsymbol{\Omega}$ given as:

$$
\boldsymbol{\Omega}=\operatorname{Cov}\left(z_{t}\right)=\mathrm{E}\left[\left(\lambda \varsigma_{t}+\varepsilon_{t}\right)\left(\lambda \varsigma_{t}+\varepsilon_{t}\right)^{\prime}\right]=\lambda \psi \lambda^{\prime}+\boldsymbol{\Theta}_{\varepsilon}
$$

In equation (7), $\psi=\operatorname{Var}\left(\varsigma_{t}\right)$ and $\boldsymbol{\Theta}_{\varepsilon}=\mathrm{E}\left(\boldsymbol{\varepsilon}_{t} \boldsymbol{\varepsilon}_{t}^{\prime}\right)$ is the measurement error's covariance matrix.

In general, estimation of a MIMIC model uses covariance information of sample data to derive estimates of population parameters. Instead of minimizing the distance between observed and predicted individual values, as in standard econometrics, the MIMIC model minimizes the distance between an observed (sample) covariance matrix and the covariance matrix pre- 
dicted by the model the researcher imposes on the data. The idea behind that approach is that the covariance matrix of the observed variables is a function of a set of model parameters:

$$
\Sigma=\Sigma(\theta)
$$

where $\Sigma$ is the population covariance matrix of the observed variables, $\boldsymbol{\theta}$ is a vector that contains the parameters of the model and $\Sigma(\boldsymbol{\theta})$ is the covariance matrix as a function of $\boldsymbol{\theta}$, implying that each element of the covariance matrix is a function of one or more model parameters. If the hypothesized model is correct and the parameters are known, the population covariance matrix would be exactly reproduced, that is, $\Sigma$ will equal $\Sigma(\theta)$. In practice, however, one does not know either the population variances and covariances or the parameters, but instead uses the sample covariance matrix and sample estimates of the unknown parameters for estimation (Bollen 1989, p. 256).

Estimation is thus performed by finding values for $\hat{\boldsymbol{\theta}}=f\left(\hat{\lambda}, \hat{\gamma}, \hat{\psi}, \hat{\boldsymbol{\Phi}}, \hat{\boldsymbol{\Theta}}_{\varepsilon}\right)$ producing an estimate of the models covariance matrix $\hat{\Sigma}$ that most closely corresponds to the sample covariance matrix $S$. During this estimation procedure, all possible matrices that meet the imposed restrictions are considered. If an estimate $\Sigma^{*}$ of $\hat{\Sigma}$ is close to $S$, one might conclude that $\boldsymbol{\theta}^{*}$ is a reasonable estimate of the model's parameters. Hence, estimation of a MIMIC model is reduced to the problem of measuring how close $\Sigma^{*}$ is to $S$ and if this estimate is the most accurate, that is, if it is the best estimate given the set of all possible estimates that meet the imposed restrictions (Long 1983b, pp. 42-5). The covariance equation of the MIMIC model can be derived and has the following functional form:

$$
\hat{\Sigma}=\left[\begin{array}{c|c}
\hat{\lambda}\left(\hat{\gamma}^{\prime} \hat{\boldsymbol{\Phi}} \hat{\gamma}+\hat{\psi}\right) \hat{\lambda}^{\prime}+\hat{\boldsymbol{\Theta}}_{\varepsilon} & \hat{\lambda} \hat{\gamma}^{\prime} \hat{\boldsymbol{\Phi}} \\
\hline \hat{\boldsymbol{\Phi}} \hat{\gamma} \hat{\lambda}^{\prime} & \hat{\boldsymbol{\Phi}}
\end{array}\right]
$$

The function measuring how close a given $\Sigma^{*}$ is to the sample covariance matrix $S$ is called the fitting function $\mathrm{F}\left(S ; \Sigma^{*}\right)$. The $\theta^{*}$ of all possible $\theta^{*}$ that meets the imposed constraints on $\lambda$, $\boldsymbol{\gamma}, \boldsymbol{\Phi}, \psi$, and $\boldsymbol{\Theta}_{\varepsilon}$ and minimizes the fitting function, given the sample covariance matrix $\boldsymbol{S}$, is the sample estimate $\hat{\boldsymbol{\theta}}$ of the population parameters. This means that if one set of estimates $\boldsymbol{\theta}_{1}^{*}$ 
produces the matrix $\Sigma_{1}^{*}$ and a second set $\boldsymbol{\theta}_{2}^{*}$ produces the matrix $\Sigma_{2}^{*}$ and if $\mathrm{F}\left(S ; \Sigma_{1}^{*}\right)<\mathrm{F}\left(S ; \Sigma_{2}^{*}\right), \Sigma_{1}^{*}$ is then considered to be closer to $S$ than $\Sigma_{2}^{*}$ (Long 1983a, p. 56).

The most widely used fitting function is the Maximum Likelihood (ML) function. ${ }^{30)}$ Under the assumption that $\boldsymbol{\Sigma}(\boldsymbol{\theta})$ and $\boldsymbol{S}$ are positive definite, that is, nonsingular, and $\mathrm{S}$ has a Wishart distribution, the following fitting function is minimized:

$$
\mathrm{F}_{\mathrm{ML}}=\log |\boldsymbol{\Sigma}(\boldsymbol{\theta})|+\operatorname{tr}\left[\boldsymbol{S} \boldsymbol{\Sigma}^{-1}(\boldsymbol{\theta})\right]-\log |\boldsymbol{S}|-(p+q)
$$

where $\log ||$ is the $\log$ of the determinant of the respective matrix and $(p+q)$ is the number of observed variables. In general, no closed form or explicit solution for the structural parameters that minimize $\mathrm{F}_{\mathrm{ML}}$ exists. Hence, the values of $\boldsymbol{\lambda}, \boldsymbol{\gamma}, \boldsymbol{\Phi}, \psi$ and $\boldsymbol{\Theta}_{\varepsilon}$ that minimize the fitting function are estimated applying iterative numerical procedures. ${ }^{31)}$ The ML estimator is widely used because of its desirable properties: ${ }^{32)}$

First, the ML estimator is asymptotically unbiased.

Second, the ML estimator is consistent, that is $\operatorname{plim} \hat{\boldsymbol{\theta}}=\boldsymbol{\theta}$ ( $\hat{\boldsymbol{\theta}}$ is the ML estimator and $\boldsymbol{\theta}$ is the population parameter).

Third, the ML estimator is asymptotically efficient, that is, among all consistent estimators no other has a smaller asymptotic variance.

Fourth, the ML estimator is asymptotically normally distributed, meaning that the ratio of the estimated parameter and its standard error approximate a z- distribution in large samples.

\footnotetext{
${ }^{30)}$ Other estimation procedures such as Unweighted Least Squares (ULS) and Generalized Least Squares (GLS) are also available. ULS has the advantage that it is easier to compute and leads to a consistent estimator without the assumption that the observed variables have a particular distribution. Important disadvantages of ULS are, however, that ULS does not lead to the asymptotically most efficient estimator of $\boldsymbol{\theta}$ and that $\mathrm{F}_{\mathrm{ULS}}$ is not scale invariant. The GLS estimator has similar statistical properties like the ML estimator but the significance tests are no longer accurate if the distribution of the observed variables has very 'fat' or 'thin' tails. Moreover, $F_{G L S}$ accepts the wrong model more often than ML and parameter estimates tend to suffer when using $\mathrm{F}_{\mathrm{GLS}}$. Thus, ML seems to be superior (see, e.g. Bollen 1989, pp. 111-15; Ollsson et al. 1999, 2000; Jöreskog and Sörbom 2001, pp. 20-4).

${ }^{31)}$ See Appendix 4C in Bollen (1989) for details.

${ }^{32)}$ The properties are only briefly reviewed. For a detailed discussion see Bollen (1989, pp. 107-23).
} 
Fifth, a final important characteristic of the ML estimator is scale invariance (Swaminathan and Algina 1978). The scale invariance property implies that changes in the measurement unit of one or more of the observed variables do not change the value of the fitting function. This means that $\hat{\lambda}, \hat{\gamma}, \hat{\boldsymbol{\Phi}}, \hat{\psi}$ and $\hat{\boldsymbol{\Theta}}_{\varepsilon}$ are the same for any change of scale.

It is widely accepted by most scholars who estimate the size and development of shadow economic activities using the MIMIC model or more general Structural Equation Models (SEMs) with more than one unobservable variable, that such an empirical exercise is a 'minefield', regardless of which method is used. For example, in evaluating the currently available shadow economy estimates of different scholars, one should keep in mind that there is no best or commonly accepted method. Each approach has its strengths and weaknesses and can provide specific insights and results. Although SEM/MIMIC model applications in economics are 'accompanied' by criticisms, they are increasingly used for estimating the shadow economy and other informal economic activities.

In comparison to other statistical methods, SEMs/MIMIC models offer several advantages for the estimation of shadow economic activities. According to Giles and Tedds (2002), the MIMIC approach is a wider approach than most other competing methods, since it allows one to take multiple indicator and causal variables into consideration at the same time. Moreover, it is quite flexible, allowing one to vary the choice of causal and indicator variables according to the particular features of the shadow economic activity studied, the period in question, and the availability of data. SEMs/MIMIC models lead to a formal estimation and to testing procedures, such as those based on the method of maximum likelihood. These procedures are well known and are generally 'optimal', if the sample is sufficiently large (Giles and Tedds 2002). Schneider and Enste (2000) emphasize that these models lead to some progress in estimation techniques for the size and development of the shadow economy, because this methodology allows a wide flexibility in its application. Therefore, they consider it potentially superior to other estimation methods. Cassar (2001) argues that, when compared to other methods, SEMs/MIMIC models do not need restrictive assumptions to operate. Analogously, Thomas (1992, p. 168) argues that the only real constraint of this approach is not in its conceptual structure, but the choice of variables. These positive aspects of the SEM approach in general and the MIMIC model in particular do not only apply in its application to the shadow economy, but to all informal economic activities. 


\subsubsection{Criticism of the MIMIC model}

Of course this method has its disadvantages or limitations, too, which are identified in the literature. The three most important points of criticism focus on the model's implementations, the sample used, and the reliability of the estimates:

(1) The most common objection estimating shadow economic activities using SEMs concerns the meaning of the latent variable (e.g. Helberger and Knepel 1988; Dell'Anno 2003). The confirmatory rather than exploratory nature of this approach means that one is more likely to determine whether a certain model is valid than to 'find' a suitable model. Therefore, it is possible that the specified model includes potential definitions or informal economic activities other than the one studied. For example, it is difficult for a researcher to ensure that traditional crime activities such as drug dealing are completely excluded from the analysis of the shadow economy. This criticism, which is probably the most common in the literature remains difficult to overcome as it goes back to the theoretical assumptions behind the choice of variables and empirical limitations on data availability.

(2) Helberger and Knepel (1988) argue that SEM/MIMIC model estimations lead to unstable coefficients with respect to changes of the sample size and alternative model specifications. Dell'Anno (2003) shows, however, that instability disappears asymptotically as the sample size increases. Another issue is the application of SEMs to time series data because only simple analytical tools such as q-and stemleaf plots are available to analyse the properties of the residuals (Dell'Anno 2003). ${ }^{33)}$

(3) Criticism is also related to the benchmarking procedure used to derive 'real world' figures of shadow economic activities (Breusch 2005a, 2005b). As the latent variable and its unit of measurement are not observed, SEMs just provide a set of estimated coefficients from which one can calculate an index that shows the dynamics of the unobservable variable. Application of the so- called calibration or benchmarking procedure, regardless which one is used, requires experimentation, and a comparison of the calibrated values in a wide academic debate. Unfortunately, at this stage of research on the application of the

33) Particularly critical are the assumptions $\mathrm{E}\left(\varsigma_{i k}^{2}\right)=\operatorname{Var}\left(\varsigma_{i}\right)$ for all $k$ (homoscedasticity assumption) and $\operatorname{Cov}\left(\varsigma_{i k}, \varsigma_{i l}\right)=0$ for all $k \neq l$ no autocorrelation in the error terms). Unfortunately, corrections for autocorrelated and heteroscedastic error terms have not yet received sufficient attention in models with unobservable variables (Bollen 1989, p. 58). An interesting exception is Folmer and Karmann (1992). 
SEM/MIMIC approach in economics it is not clear which benchmarking method is the best or the most reliable. ${ }^{34)}$

The economic literature using SEMs is well aware of these limitations. Consequently, it acknowledges that it is not an easy task to apply this methodology to an economic dataset, but also argues that this does not mean one should abandon the SEM approach. On the contrary, following an interdisciplinary approach to economics, SEMs are valuable tools for economic analysis, particularly when studying the shadow economy. However, the mentioned objections should be considered as an incentive for further (economic) research in this field rather than as a suggestion to abandon this method. Again going back to the definition of the shadow economy, the MIMIC estimation provides upper bound macro value added figures, including mostly legally bought material.

\subsection{Results of the size of the German shadow economy using the various estimation methods}

Finally, so that the interested reader sees how big the variance of the different estimations of the size of the shadow economy is, the results for the case of Germany are shown. A significant amount of empirical work has been done on the shadow economy in Germany, and this makes it an interesting case study. The results are shown in table 3.1. The oldest estimate uses the survey method of the Institut für Demoskopie (IfD) in Allensbach (Germany) and shows that the shadow economy was $3.6 \%$ of official GDP in 1974. In a much later study Feld and Larsen $(2005,2009)$ undertook an extensive research project using the survey method to estimate shadow economy activities in the years 2001 to 2006. Using the officially paid wage rate, they concluded that the shadow economy activities reached from $4.1 \%$ in $2001,3.1 \%$ in 2004, 3.6\% in 2005 and $2.5 \%$ in 2006. Using the much lower shadow economy wage rate, these estimates shrink, however, to $1.3 \%$ in 2001 and $1.0 \%$ in 2004, respectively.

As discussed, we know that the survey method underestimates the size of the shadow economy. Using the discrepancy method and applying national income statistics, Lippert and Walker (1997) estimate a size of the German shadow economy from 1970 to 1980 between $11.0 \%$ and $13.4 \%$ of official GDP. Using the discrepancy method applying official and actual em-

\footnotetext{
${ }^{34)}$ See Dell'Anno and Schneider (2009) for a detailed discussion on different benchmarking procedures.
} 
ployment, Langfeldt (1983) gets much higher estimates for 1970 to 1980, ranging from 23.0\% to $34.0 \%$. Applying the physical input method (electricity approach), Feld and Larsen (2005) get results of $14.5 \%$ for the year 1985 and $14.6 \%$ for 1990 . The monetary transaction method developed by Feige calculates the shadow economy to be of about 30\% between 1980 and 1985. These are the highest estimates for the case of Germany. Switching to the currency demand approach, first used by Kirchgässner $(1983,1984)$, his study provides values of $3.1 \%$ in 1970 and $10.3 \%$ in 1980 . Kirchgässner's values are quite similar to those obtained by Schneider and Enste (2000, 2002), who also use the currency demand approach to estimate the size of the shadow economy, which are $4.5 \%$ in 1970 and $14.7 \%$ in 2000 . Using the MIMIC estimation procedure, which was first applied by Frey and Weck (1983), the results are quite similar to those from the currency demand approach. ${ }^{35)}$ Frey and Weck (1983) calculate a shadow economy in Germany in 1970 of $5.8 \%$ which increases to $8.2 \%$ in 1980. Pickardt and Sarda (2006), whose sample used for the MIMIC estimations started a bit later, get a value of $9.4 \%$ in 1980 , which increases to $16.3 \%$ in the year 2000 . These are quite similar values to Schneider (2005, 2007). Finally, using the soft modeling variant of the MIMIC approach, WeckHannemann (1983) gets a value of 8.3\% of GDP in 1975.

Considering table 3.1, one can see that different estimation procedures produce different results. It is safe to say that the figures produced by the transactions and discrepancy approaches are unrealistically large. A size of the shadow economy of almost one third of official GDP in the mid-eighties is most likely to be an overestimate. The figures obtained using the currency demand and the hidden (latent, MIMIC) approaches are, on the other hand, relatively close together and much lower than those produced by the discrepancy or transactions approach. The estimates from the MIMIC approach can be regarded as the most reasonable estimates of the size of the shadow economy and the survey model is likely to produce too low estimates for the reasons already discussed.

Finally, in table 3.2 a comparison of the size of the German shadow economy using the survey and the MIMIC method for the year 2006 is undertaken. As we see, the difference between the estimates of the macro-method (here the MIMIC estimation procedure) and the results from the survey method is quite large. In table 3.2 an attempt is undertaken to demonstrate the major difference between these two estimation methods. The first line of table 3.2 clearly shows shadow economy activities from labor (hours worked, survey results). They

\footnotetext{
${ }^{35)}$ This is not astonishing as quite often the calibration start-values have been used from the currency demand approach in order to transform the relative estimates of the MIMIC approach.
} 
range from $5.0 \%-6.0 \%$ in the year 2006. If one adds to this used material, illegal activities and those which are already included in the official GDP, one gets a value between $13.0 \%$ and $17.0 \%$ of GDP, which comes very close to the $15.0 \%$ of the MIMIC estimation results. Hence, one realizes that the macro-results of course include the used materials and illegal activities, so that it is not amazing to find much larger results. 
Table 3.1: The size of the shadow economy in Germany according to different methods (in percentage of official GDP)

\begin{tabular}{|c|c|c|c|c|c|c|c|c|}
\hline \multirow[t]{2}{*}{ Method/Source } & \multicolumn{8}{|c|}{ Shadow economy (in percentage of official GDP) in: } \\
\hline & 1970 & 1975 & 1980 & 1985 & 1990 & 1995 & 2000 & 2005 \\
\hline \multirow{3}{*}{$\begin{array}{l}\text { Survey } \\
\text { (IfD Allensbach, 1975) } \\
\text { (Feld and Larsen, 2005) }\end{array}$} & - & $3.6^{1)}$ & - & - & - & - & - & - \\
\hline & - & - & - & - & - & - & $4.1^{2)}$ & $3.1^{2)}$ \\
\hline & - & - & - & - & - & - & $1.3^{3)}$ & $1.0^{3)}$ \\
\hline $\begin{array}{l}\text { Discrepancy between expenditure and } \\
\text { income } \\
\text { (Lippert and Walker, 1997) }\end{array}$ & 11.0 & 10.2 & 13.4 & - & - & - & - & - \\
\hline $\begin{array}{l}\text { Discrepancy between official and actual } \\
\text { employment } \\
\text { (Langfeldt, 1983) }\end{array}$ & 23.0 & 38.5 & 34.0 & - & - & - & - & - \\
\hline $\begin{array}{l}\text { Physical input method } \\
\text { (Feld and Larsen, 2005) }\end{array}$ & - & - & - & 14.5 & 14.6 & - & - & - \\
\hline Transactions approach & 17.2 & 22.3 & 29.3 & 31.4 & - & - & - & - \\
\hline \multirow{3}{*}{$\begin{array}{l}\text { Currency demand approach (Kirchgäss- } \\
\text { ner, 1983) } \\
\text { (Langfeldt, 1983, 1984) } \\
\text { Schneider and Enste (2000) }\end{array}$} & 3.1 & 6.0 & 10.3 & - & - & - & - & - \\
\hline & 12.1 & 11.8 & 12.6 & - & - & - & - & - \\
\hline & 4.5 & 7.8 & 9.2 & 11.3 & 11.8 & 12.5 & 14.7 & - \\
\hline \multirow{3}{*}{$\begin{array}{l}\text { Latent ((DY)MIMIC) approach } \\
\text { Frey and Weck (1983) } \\
\text { Pickardt and Sarda }(2006) \\
\text { Schneider }(2005,2007)\end{array}$} & 5.8 & 6.1 & 8.2 & - & - & - & - & - \\
\hline & - & - & 9.4 & 10.1 & 11.4 & 15.1 & 16.3 & - \\
\hline & 4.2 & 5.8 & 10.8 & 11.2 & 12.2 & 13.9 & 16.0 & 15.4 \\
\hline $\begin{array}{l}\text { Soft modellingWeck-Hannemann } \\
\text { (1983) }\end{array}$ & - & 8.3 & - & - & - & - & - & - \\
\hline
\end{tabular}

1) 1974.

2) 2001 and 2004; calculated using wages in the official economy.

3) 2001 and 2004; calculated using actual "black" hourly wages paid. 
Table 3.2: A comparison of the size of the German shadow economy using the survey and the MIMIC-method, year 2006

\begin{tabular}{|c|c|c|c|}
\hline $\begin{array}{c}\text { Various kinds of shadow economy } \\
\text { activities/values }\end{array}$ & $\begin{array}{l}\text { Shadow Econ- } \\
\text { omy in \% of } \\
\text { official GDP }\end{array}$ & $\begin{array}{l}\text { Shadow } \\
\text { Economy in } \\
\text { bill. Euro }\end{array}$ & $\begin{array}{l}\text { \% share of the } \\
\text { overall shad- } \\
\text { ow economy }\end{array}$ \\
\hline $\begin{array}{l}\text { Shadow economy activities from } \\
\text { labor (hours worked, survey results) } \\
+ \text { Material (used) } \\
+ \text { Illegal activities (goods and ser- } \\
\text { vices) } \\
+ \text { already in the official GDP includ- } \\
\quad \text { ed illegal activities }\end{array}$ & $\begin{array}{l}5.0-6.0 \\
3.0-4.0 \\
4.0-5.0 \\
1.0-2.0\end{array}$ & $\begin{array}{l}117-140 \\
70-90 \\
90-117 \\
23-45\end{array}$ & $\begin{array}{c}33-40 \\
20-25 \\
25-33 \\
7-13\end{array}$ \\
\hline Sum (1) to (4) & $13.0-17.0$ & $300-392$ & $85-111$ \\
\hline $\begin{array}{l}\text { Overall (total) shadow economy (es- } \\
\text { timated by the MIMIC and calibrated } \\
\text { by the currency demand procedure) }\end{array}$ & 15.0 & 340 & 100 \\
\hline
\end{tabular}

\section{THE SIZE OF THE SHADOW ECONOMY ALL OVER THE WORLD}

Figure 4.1 shows the average size of the shadow economy of 162 countries over 1999-2007 ${ }^{36)}$. In tables 4.1 und 4.2 the average informality (unweighted and weighted) in different regions is shown using the regions defined by the World Bank. The World Bank distinguishes 8 world regions which are East Asia and Pacific, Europe and Central Asia, Latin America and the Caribbean, Middle East and North Africa, High Income OECD, Other High Income, South Asia, and Sub-Saharan Africa. If we consider first table 4.1 where the average informality (unweighted) is shown, we see that Latin America and the Caribbean have the highest value of the shadow economies of $41.1 \%$, followed by Sub-Saharan Africa of $40.2 \%$ and then followed by Europe and Central Asia of $38.9 \%$. The lowest have the High Income OECD countries with $17.1 \%$. If we consider the average informality of the shadow economies of these regions weighted by total GDP in 2005, Sub-Saharan Africa has the highest with $37.6 \%$, followed by Europe and Central Asia with $36.4 \%$ and Latin America and the Caribbean with $34.7 \%$. The lowest again has the High Income OECD with $13.4 \%$. If one considers the world

\footnotetext{
${ }^{36)}$ Some figures are taken from Schneider, Buehn and Montenegro (2010). The econometric MIMIC estimation results are not shown here due to space reasons; see e.g. Schneider, Buehn and Montenegro (2010).
} 
mean weighted and unweighted, one sees that if one uses the unweighted measures the mean is $33.0 \%$ over the periods $1999-2007$. If we consider the world with weighted informality measures the shadow economy takes "only" a value of $17.1 \%$ over the period 1999-2007. Weighting the values makes a considerable difference.

One general result of the size and development of the shadow economies worldwide is that there is an overall reduction in the size. In figure 4.2 the size and development of the shadow economy of various countries groups (weighted averages by the official GDP of 2005) over 1999, 2003 and 2007 are shown. One clearly realizes that for all countries groups (25 OECD countries, 116 developing counties, 25 transition countries) I observe a decrease in the size of the shadow economy. The average size of the shadow economies of the 162 countries was $34.0 \%$ of official GDP (unweighted measure!) in 1999 and decreased to 31.2\% of official GDP in 2007. This is a decrease of almost 3.0 percentage points over 9 years. Growth of the official economy with reduced (increased) unemployment (employment) seems to be the most efficient mean to reduce the shadow economy.

Table 4.1: Average informality (unweighted) by World Bank's regions

\begin{tabular}{|l|c|c|c|c|c|}
\hline \multirow{2}{*}{ Region } & \multicolumn{5}{|c|}{ Values } \\
\cline { 2 - 6 } & mean & median & min & max & sd \\
\hline East Asia and Pacific (EAP) & 32.3 & 32.4 & 12.7 & 50.6 & 13.3 \\
\hline Europe and Central Asia (ECA) & 38.9 & 39.0 & 18.1 & 65.8 & 10.9 \\
\hline Latin America and the Caribbean (LAC) & 41.1 & 38.8 & 19.3 & 66.1 & 12.3 \\
\hline Middle East and North Africa (MENA) & 28.0 & 32.5 & 18.3 & 37.2 & 7.8 \\
\hline High Income OECD (OECD) & 17.1 & 15.8 & 8.5 & 28.0 & 6.1 \\
\hline Other High Income (OHIE) & 23.0 & 25.0 & 12.4 & 33.4 & 7.0 \\
\hline South Asia (SAS) & 33.2 & 35.3 & 22.2 & 43.9 & 7.0 \\
\hline Sub-Saharan Africa (SSA) & 40.2 & 40.6 & 18.4 & 61.8 & 8.3 \\
\hline World & 33.0 & 33.5 & 8.5 & 66.1 & 12.8 \\
\hline
\end{tabular}

Source: Schneider, Buehn and Montenegro (2010) 
Table 4.2: Average informality (weighted) by total GDP in 2005

\begin{tabular}{|l|c|c|c|c|c|}
\hline \multirow{2}{*}{ Region } & \multicolumn{5}{|c|}{ Values } \\
\cline { 2 - 6 } & mean & median & min & max & sd \\
\hline East Asia and Pacific (EAP) & 17.5 & 12.7 & 12.7 & 50.6 & 10.6 \\
\hline Europe and Central Asia (ECA) & 36.4 & 32.6 & 18.1 & 65.8 & 8.4 \\
\hline Latin America and the Caribbean (LAC) & 34.7 & 33.8 & 19.3 & 66.1 & 7.9 \\
\hline Middle East and North Africa (MENA) & 27.3 & 32.5 & 18.3 & 37.2 & 7.7 \\
\hline High Income OECD (OECD) & 13.4 & 11.0 & 8.5 & 28.0 & 5.7 \\
\hline Other High Income (OHIE) & 20.8 & 19.4 & 12.4 & 33.4 & 4.9 \\
\hline South Asia (SAS) & 25.1 & 22.2 & 22.2 & 43.9 & 5.9 \\
\hline Sub-Saharan Africa (SSA) & 37.6 & 33.2 & 18.4 & 61.8 & 11.7 \\
\hline World & 17.1 & 13.2 & 8.5 & 66.1 & 9.9 \\
\hline
\end{tabular}

Source: Schneider, Buehn and Montenegro (2010) 
Figure 4.1: Average size of the shadow economy of 162 countries over 1999-2007

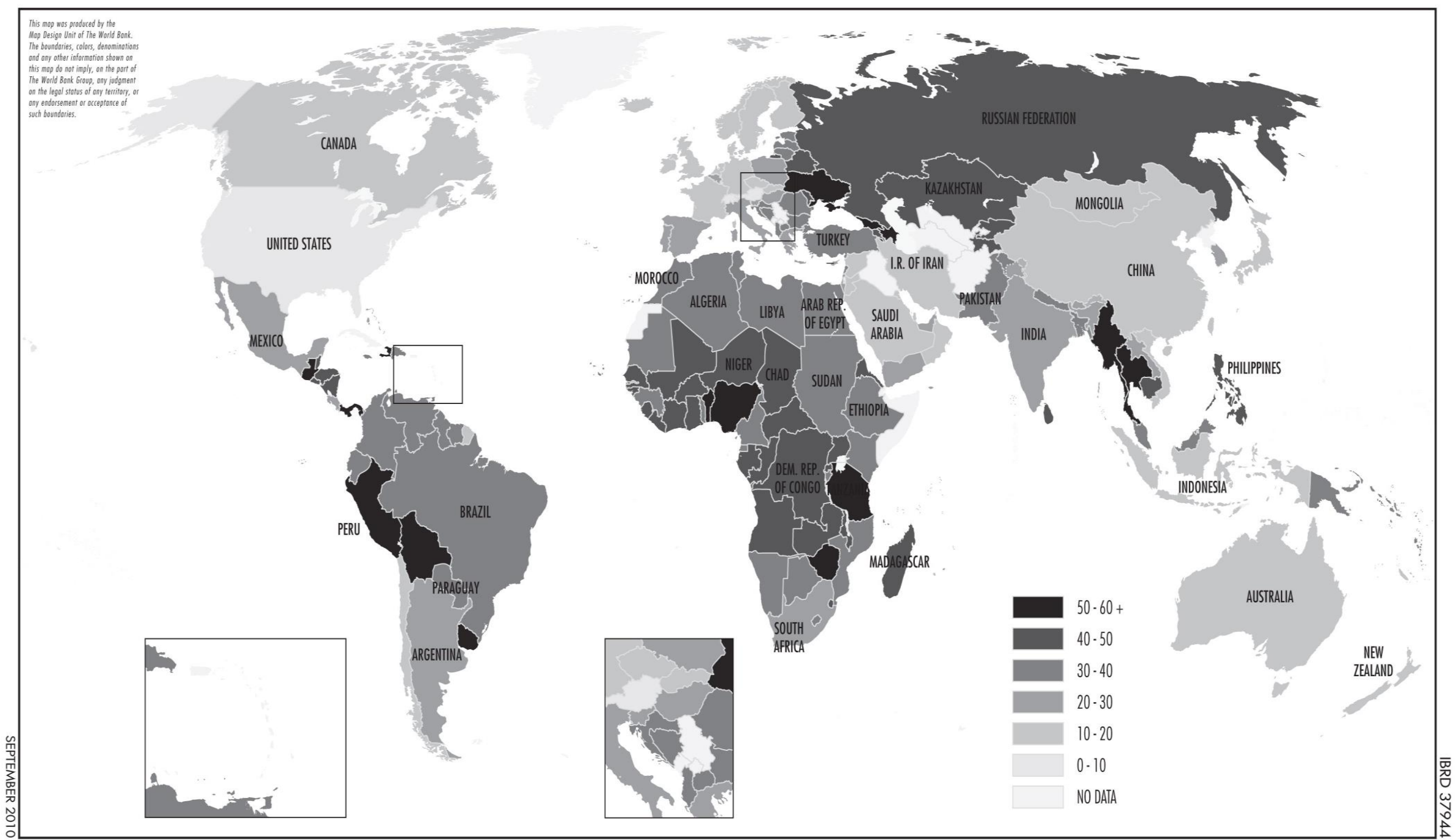

Source: Schneider, Buehn and Montenegro (2010) 
Figure 4.2: Size and development of the shadow economy of various country groups (weighted averages (!); in percent of official total GDP of the respective country group)

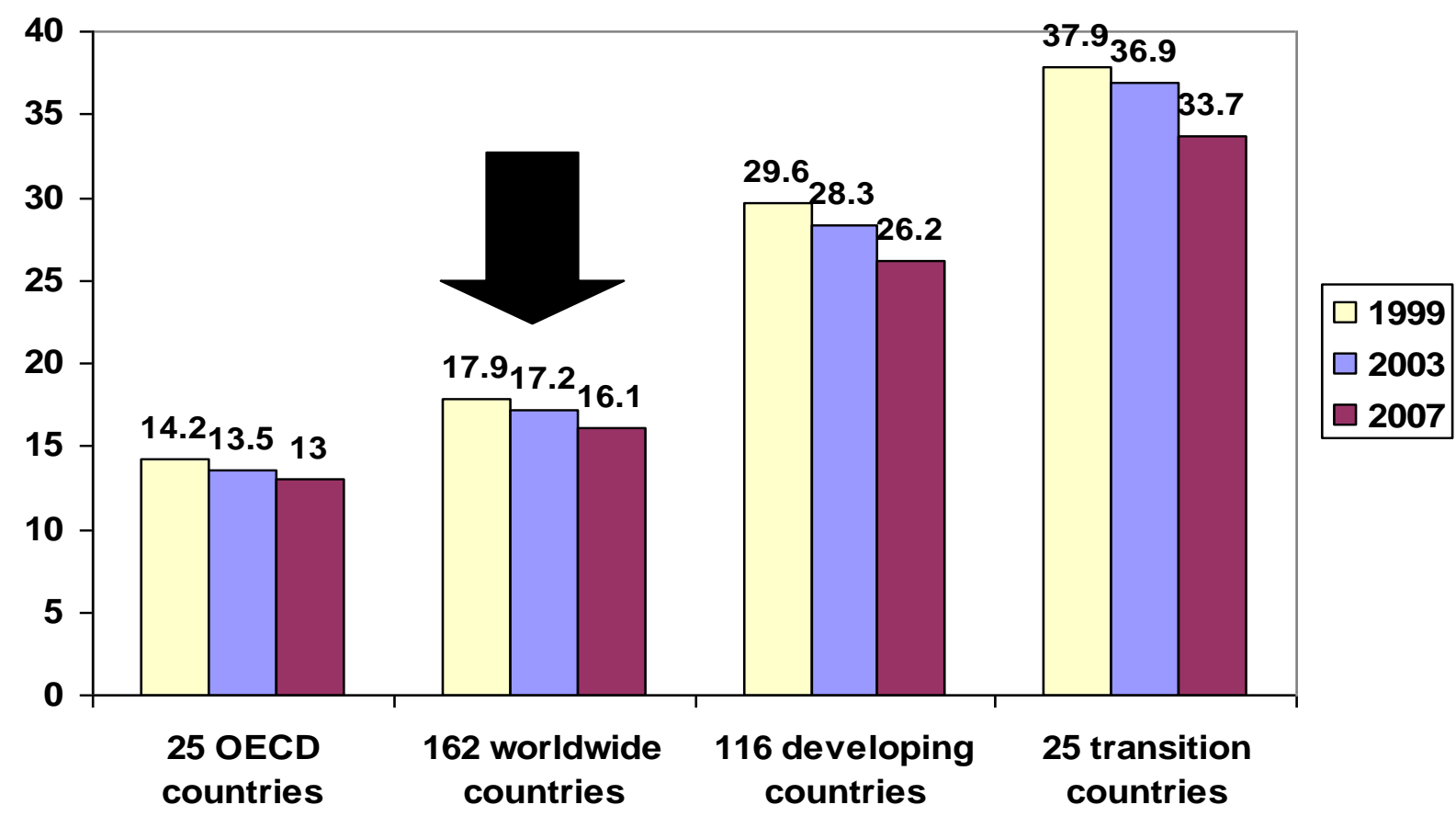

Source: Schneider, Buehn and Montenegro (2010)

\section{SHADOW ECONOMY LABOR FORCE AND LABOR MARKET ${ }^{37)}$}

\subsection{Shadow economy labor market}

Having examined the size, rise and fall of the shadow economy in terms of value added over time, the analysis now focuses on the "shadow labor market", as within the official labor market there is a particularly tight relationship and "social network" between people who are active in the shadow economy ${ }^{38)}$. Moreover, by definition every activity in the shadow economy involves a "shadow labor market" to some extent ${ }^{39)}$ : Hence, the "shadow labor market" includes all cases, where the employees or the employers, or both, occupy a "shadow economy position“.

\footnotetext{
${ }^{37)}$ The literature of the shadow labor force has strongly increased and is not discussed here, compare e.g. Williams (2007, 2009, 2013), Williams and Windebank (1998), Williams and Lansky (2013) and Williams and Rodgers (2013).

${ }^{38)}$ Pioneering work in this area has been done by L. Frey (1972, 1975, 1978, 1980), Cappiello (1986), Lubell (1991), Pozo (1996), Bartlett (1998) and Tanzi (1999). One of the latest surveys or background paper is Hazans (2011) dealing with informal workers across Europe.

${ }^{39)}$ Compare also one of the latest OECD report with the title "Is Informal Normal: Toward More and Better Jobs" by the OECD (2009a, b).
} 
Why do people work in the shadow economy? In the official labor market, the costs firms (and individuals) have to pay when "officially" hiring someone are tremendously increased by the burden of tax and social contributions on wages, as well as by the legal administrative regulation to control economic activity. In various OECD countries, these costs are greater than the wage effectively earned by the worker - providing a strong incentive to work in the shadow economy.

More detailed theoretical information on the labor supply decision in the underground economy is given by Lemieux, Fortin and Fréchette (1994) who use micro data from a survey conducted in Quebec City (Canada). In particular, their study provides some economic insights regarding the size of the distortion caused by income taxation and the welfare system. The results of this study suggest that hours worked in the shadow economy are quite responsive to changes in the net wage in the regular (official) sector. Their empirical results attribute this to a (mis-) allocation of work from the official to the informal sector, where it is not taxed. In this case, the substitution between labor market activities in the two sectors is quite high. These empirical findings indicate, that "participation rates and hours worked in the underground sector also tend to be inversely related to the number of hours worked in the regular sector“ (Lemieux, Fortin and Fréchette 1994, p. 235). These findings demonstrate a large negative elasticity of hours worked in the shadow economy with respect both to the wage rate in the regular sector as well as to a high mobility between the sectors.

Illicit work can take many forms. The underground use of labor may consist of a second job after (or even during) regular working hours. A second form is shadow economy work by individuals who do not participate in the official labor market. A third component is the employment of people (e.g. clandestine or illegal immigrants), who are not allowed to work in the official economy. Empirical research on the shadow economy labor market is even more difficult than of the shadow economy on the value added, since one has very little knowledge about how many hours an average "shadow economy worker" is actually working (from full time to a few hours, only); hence, it is not easy to provide empirical facts ${ }^{40)}$.

Kucera and Roncolato (2008, p. 321) also deal with informal employment. They address two issues of crucial importance to labor market policy:

\footnotetext{
${ }^{40)}$ For developing countries some literature about the shadow labor market exists (Dallago (1990), Pozo (1996), Loayza (1996), Chickering and Salahdine (1991) and OECD (2009a, b)).
} 
i. The intensive labor market regulations as one (major) cause of informal employment, and

ii. the so-called "voluntary" informal employment. Kucera and Roncolato give a theoretical overview on both issues and also a survey of a number of empirical studies, in which mainly the effect of official labor market regulations on informal employment is analyzed, where they find a significant and quantitatively important influence.

\subsection{Two micro-studies about the shadow economy labor market}

To discuss some micro-economic research about the shadow economy labor market two case studies about the size and development of shadow economy labor markets in Denmark and in Germany are presented and discussed ${ }^{41)}$.

\subsubsection{The micro-study of Denmark}

The first study is done by Hvidtfeldt, Jensen and Larsen (2011), which investigates the size and development of undeclared work in Denmark over the years 2008-2010, but also going back to the year 1994. Hvidtfeld, Jensen and Larsen (2011, p. 1) claim that more than half of all Danes purchase undeclared work in the course of a year. The authors got this finding with the help of an interview survey of 2.200 randomly-selected Danes who were conducted by the Rockwool Foundation Research Unit in 2010. According to their survey, 52\% of those questioned had had undeclared work done for them in the previous year and had paid in cash, in kind or through return services. Their survey $(2011$, p. 2) also showed that an additional $28 \%$ would be willing to buy undeclared services, even though they had not actually done so within the previous year. In total, $80 \%$ of the Danish population are potential customers for undeclared work and only $20 \%$ said, they would refuse to pay for undeclared services.

In table 5.1 the proportions of Danish men are shown who carried out undeclared work in the previous 12 month (year 2010). Table 5.1 clearly says that $48 \%$ of such undeclared work is

\footnotetext{
${ }^{41)}$ The selection of these two studies is based on the fact that they use data from 2010 and both provide important and detailed insights, why people choose to demand and supply shadow work. Of course this selection is subjective. Compare also Feld and Larsen (2005, 2008, 2009), Schneider (2011), and especially Williams (2007, 2009, 2013).
} 
done in the construction sector, followed by agriculture of $47 \%$ and motor vehicle sales and repairs of $43 \%$. The least amount is done in the public and personal services with $26 \%$.

Table 5.1: Proportions of men who had carried out undeclared work in the previous 12 months

\begin{tabular}{|l|l|}
\hline SECTOR & in percent \\
\hline Building and construction & $48 \%$ \\
\hline Agriculture (incl. gardening), fishing and mineral extraction & $47 \%$ \\
\hline Motor vehicle sales and repairs & $43 \%$ \\
\hline Energy and water supply & $(38 \%)$ \\
\hline Manufacturing & $36 \%$ \\
\hline Transport and telecommunications & $31 \%$ \\
\hline Hotel and restaurant & $(30 \%)$ \\
\hline Financial and business services & $28 \%$ \\
\hline Public and personal services & $26 \%$ \\
\hline Retail, wholesale and repair (excluding motor vehicles) & $26 \%$ \\
\hline OVERALL & $\mathbf{3 2 \%}$ \\
\hline
\end{tabular}

Note: Figures in parentheses are based on fewer than 50 observations.

Source: Hvidtfeldt et al., 2011, p. 5

In this study the authors also investigate the amount of undeclared work since the year 1994 and they come to the conclusion that Danes do roughly as much undeclared work today as they did 15 years ago. The latest figures from 2008-2010 show that every forth adult Dane carried out some kind of undeclared work in the course of a year. Those involved spend around three hours per week working on the undeclared labor market. This figure has not changed since the mid-1994. Calculations of the amount of undeclared work in relation to GDP also show that the situation remains largely unchanged. Undeclared work mostly done in the household is at a level of $2.8 \%$ in relation to $\mathrm{GDP}^{42)}$.

Finally what is a quite interesting result of this study, is the acceptance of black labor among the Danish population.

\footnotetext{
${ }^{42)}$ In this study a lot of interesting facts are reported, like who is working, like distribution of men and women in the shadow economy, like, how much is paid per hour in the different sectors, etc. Also it is investigated whether high income households demand more or less shadow economy work and it seems they demand more.
} 
Table 5.2.A: Proportion of the Danish population who find it acceptable that a schoolgirl should earn undeclared income for babysitting, 2007-2008.

$\begin{array}{ll}\text { If she earns DKK } 200 \text { per week } & 84 \% \\ \text { If she earns DKK } 300 \text { per week } & 70 \%\end{array}$

Source: Rockwool Foundation Research Unit, March 2011, p.14

Table 5.2.B: Proportion of the Danish population who find it acceptable that a skilled tradesman should earn undeclared income, 2007-2008.

$\begin{array}{ll}\text { If he earns DKK 10.000 per year } & 47 \% \\ \text { If he earns DKK 50.000 per year } & 27 \%\end{array}$

Source: Hvidtfeldt et al., 2011, p. 14.

The Danish population evaluates a school girl who earns some money in the shadow economy, and was asked about the acceptance and the same question was asked about a skilled tradesman. The results are reported in the tables 5.2.A and 5.2.B. They clearly show that there is a high acceptance of shadow economy labor work for a school girl compared to a wellestablished skilled tradesman with a reasonable high income. Not astonishing for the school girl the acceptance is $70 \%$ earning 300 DKK per week and 84\% earning 200 DKK per week. For the tradesman to earn additional 10.000 DKK per year the acceptance drops down to $47 \%$ (below 50\%) and if he earns more than 50.000 DKK per year the acceptance is only $27 \%$. It is a quite interesting finding which demonstrates that Danes tolerate shadow economy earnings from low income earners but not from high income earners.

\subsubsection{The micro-study of Germany}

Haigner, Jenewein, Schneider and Wakolbinger (2013) investigate the informal labor supply and demand in Germany for the year 2010. In this study they use data from a representative survey among 2104 German residents, conducted in May 2010. As a matter of fact, questions on illegal behavior like informal labor supply and demand are highly confidential and delicate; hence it is possible that survey respondents who have engaged in such activities do 
not want to declare that they have done so. In order to encourage more honest answers, the interviewees have been read the following text (translated from German).

"The next set of questions deals with what is called black work. We survey these questions on behalf of a group of independent scientists, who will process the results within a study. By black work they mean the following: One works for somebody and agrees not to pay taxes for the payment. Both partners are better off because no value added tax, income tax or social security contributions are paid. Such procedures are frequently occurring, for example, in cleaning, gardening, baby-sitting, waiting at table, writing or programming. Also, work which is not taxed is prevalent in construction, renovation, car repair and taking care of elderly people."

Moreover, if interviewers recognized that the interviewees hesitated to answer the questions on informal labor supply and demand, they would again note that the interview is confidential and that answers are confidential, anonymous and only for scientific use. The question on informal labor supply was (translated from German) "Have you, during the last year, worked for somebody in the way described above (black work)?" The question on informal labor demand was (again translated from German) "Have you, during the last year, demanded black work?" Moreover, they have asked informal labor suppliers on the reasons for doing so, on the time when they have done such works (working time, weekends, vacations,...), on the sector in which they have worked, on the number of hours they have worked per month and on the estimated hourly wage they have received.

In order to grasp the general attitudes towards informal labor supply and demand, they have asked the survey respondents to declare their accordance with a set of 13 statements on the topic. Possible answers were indicated on a scale ranging from -4 (total disagreement) to +4 (total agreement). Figure 5.1 shows the results. While there seems to be considerable awareness of the fact that informal labor reduces the tax revenues of the state, many people claim, on the other hand, that high tax rates make attractive the informal labor market. Interestingly, many people like informal labor because it is more rapidly available and more flexible than official labor, which is widely perceived to be subject to too strict regulations. Moreover, people, on average, do not agree with the statement that informal labor suppliers should be reported to the police, nor would many people report them to the police themselves. This shows that informal labor is, in Germany, perceived as a rather trivial offense. 


\section{Figure 5.1: Attitudes towards informal labor supply and demand}

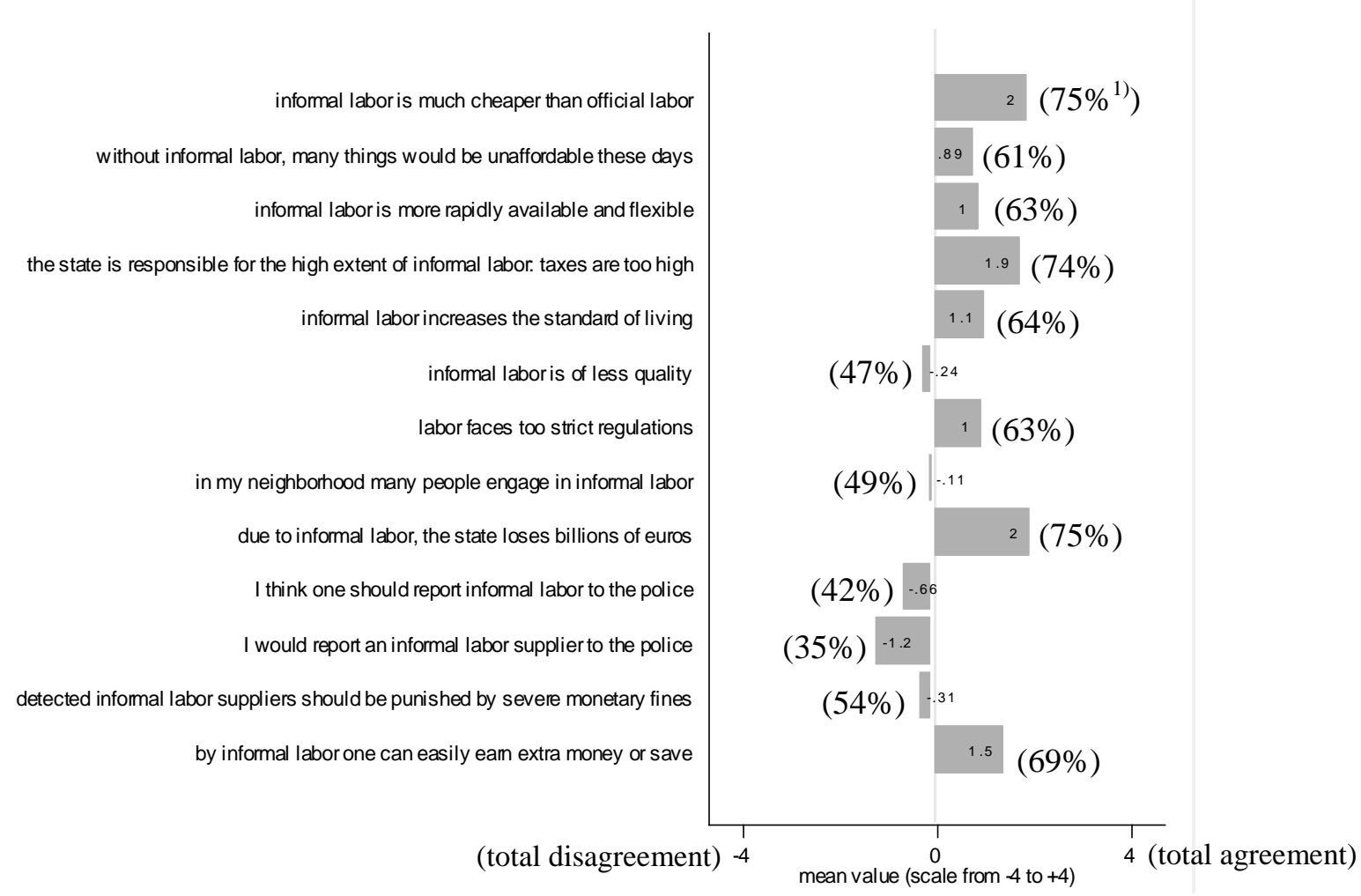

1) in ( ) percenteage points of agreement

Source: Haigner et al. (2013)

\section{(1) Informal Labor Supply}

Out of 2104 respondents, 285 (13.55\%) declared that they have been supplying informal labor during the year before the survey. Among men, the fraction of informal labor suppliers was significantly higher (18.82\%) than among women (8.58\%) (Mann-Whitney U-Test, N=2104, $\mathrm{p}=0.00$ ). Moreover, the authors find above average fractions of informal labor suppliers among the unemployed (29.29\%) and people out of labor force "due to other reasons" $(23.53 \%)$. Among pensioners $(5.10 \%)$ and housewives and housemen $(9.52 \%)$ the fraction is below the average, while it is close to the average among students (14.44\%), apprentices (11.75\%), self-employed persons (15.17\%) and dependent employees (15.60\%). Among persons not having completed compulsory education and those who have completed an apprenticeship, informal labor suppliers are overrepresented (24.24\% and $20.41 \%)$, while they are underrepresented among persons with a university degree (7.19\%). 


\section{(2) Sectors of Informal Labour Supply}

Figure 5.2 shows in which sectors informal labor supply takes place. Not surprisingly, crafts and technical occupations and private household services have the highest relative importance. In both branches, more than a quarter of informal labor suppliers are engaged. About $15 \%$ of informal labor suppliers declare to be working in other services, gardening/agriculture and construction. Fractions do not add up to $100 \%$ since multiple answers have been allowed.

\section{Figure 5.2: Sectors of informal labor supply}

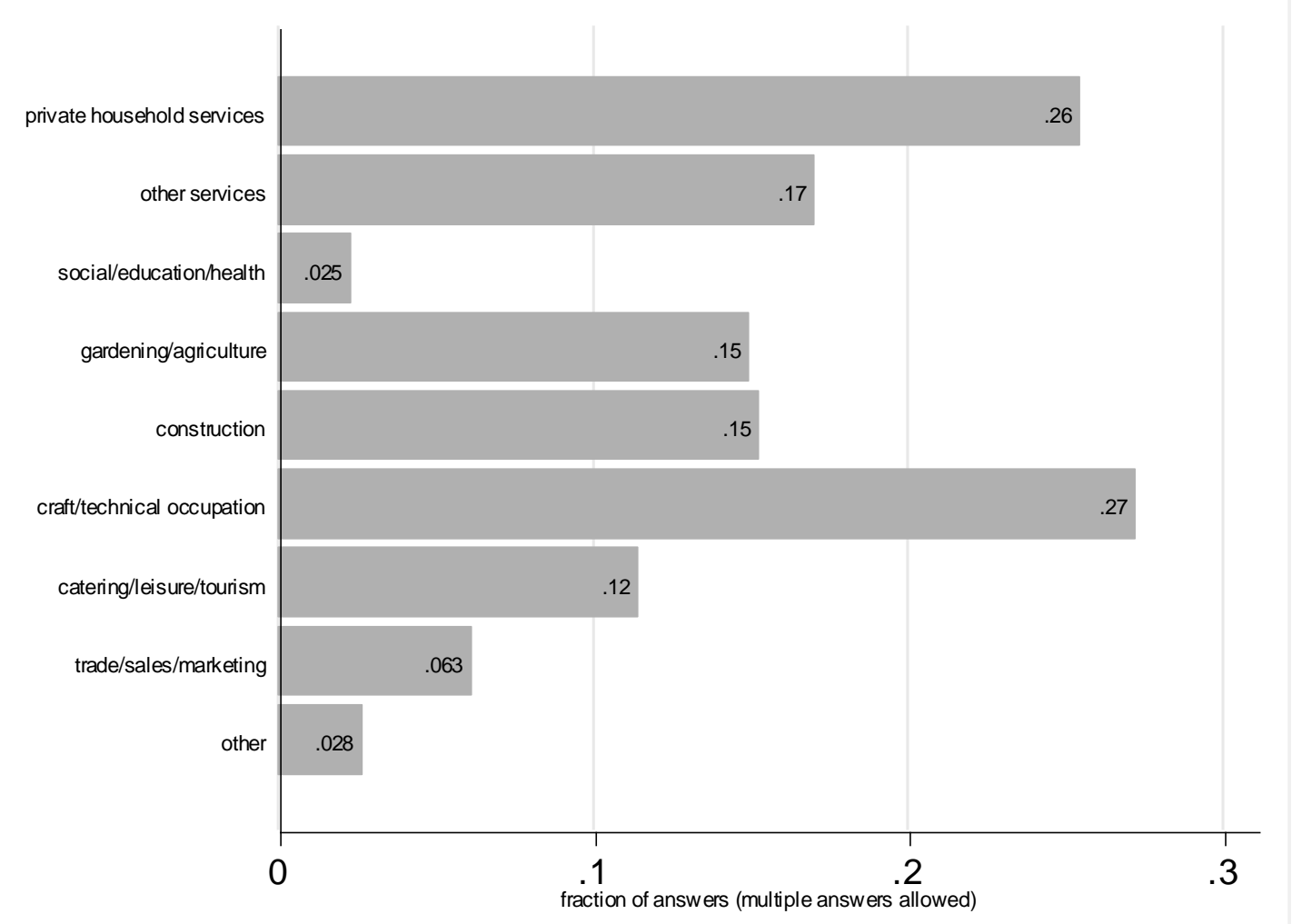

Source: Haigner et al.(2013)

\section{(3) Directly reported reasons}

The authors have directly asked the survey respondents (declaring to engage in informal labor supply) for the reasons for doing so. Again, the results are as expected. Figure 5.3 shows that four in five declare to supply informal labor in order to earn more money. All other noted reasons are far less important. However, it is interesting to see, for example, that one in about eight informal labor suppliers do so because they do not want to lose transfer payments. In the German social system, pensioners as well as unemployment benefit and social assistance 
recipients face a full transfer cut and thus implicit marginal tax rates of $100 \%$ and more if they would officially supply labor.

More than one in five informal labor suppliers claim that a reason for doing so is that others do it as well. This result is in line with our (earlier reported) finding that German residents perceive, in general, informal labor supply and demand as a rather trivial offence. By the same token, slightly more than ten percent of informal labor suppliers claim that they do so because their customers want the demanded work to be done unofficially. Another ten percent say that they like the flexibility of informal labor supply ${ }^{43)}$.

\section{Figure 5.3: Directly reported reasons for supplying informal labor}

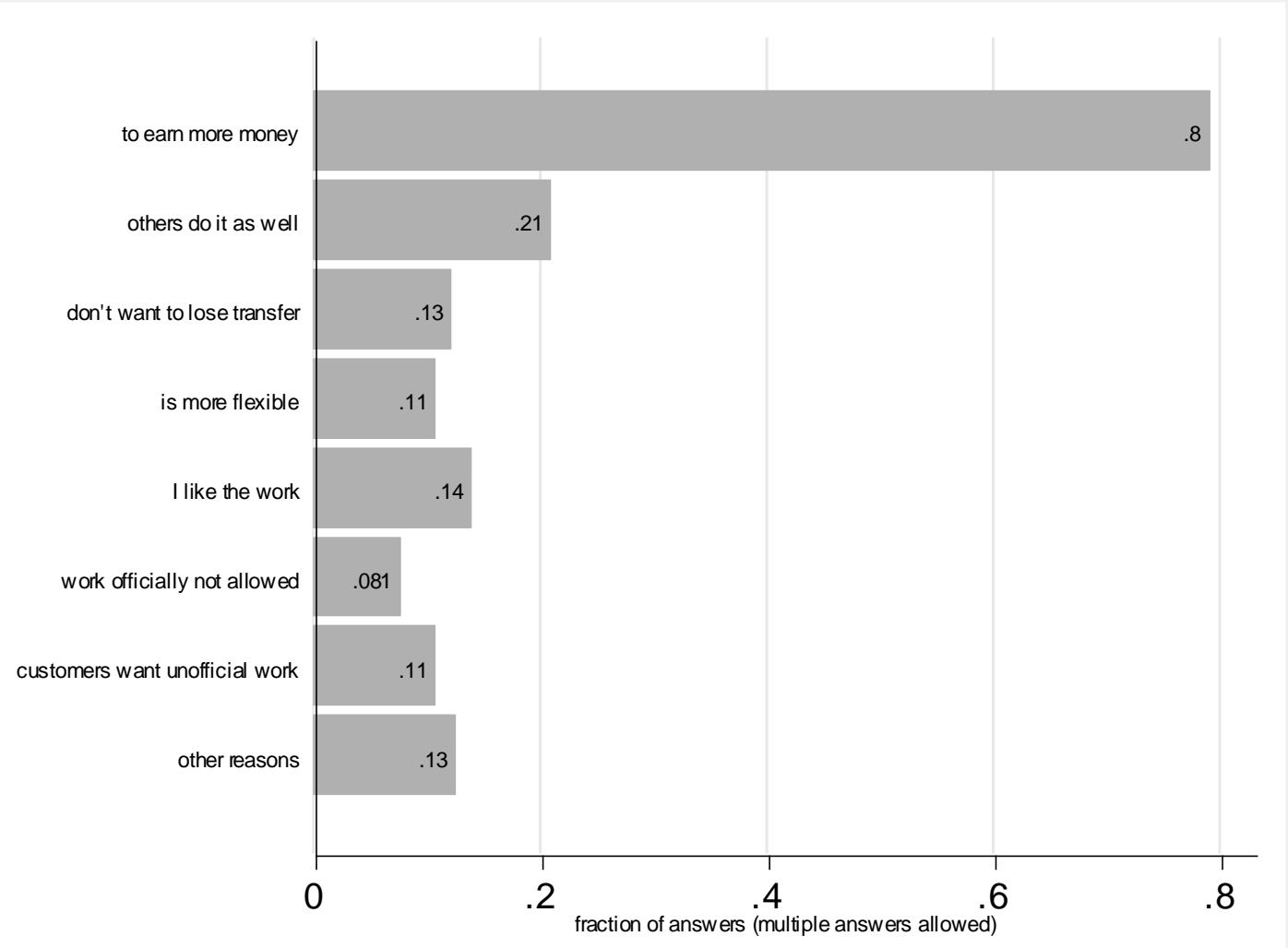

Source: Haigner et al. (2013)

\footnotetext{
${ }^{43)}$ In this study also a microeconemetric investigation is undertaken confirming the facts discussed here under ceteris paribus conditions.
} 


\section{(4) Regressions on informal labour supply and demand ${ }^{44)}$}

In order to fulfill the ceteris paribus conditions, Haigner et al. (2013) use probit regressions ${ }^{45)}$ to find out what the driving forces of informal labour supply and demand are ${ }^{46)}$. This enables us to determine the marginal effects on the probability of supplying and using informal labour. Haigner et al. (2013) estimate separate regressions for women and men in order to enable differentiation by sex, and use the explanatory variables described below.

\section{(5) Results of informal labour supply}

The results of Haigner et al. (2013) of the probit regressions on informal labour supply by men and women are shown in table 5.3. One of their main findings is that people who are currently unemployed, as well as those who have been unemployed in the past, have a higher probability, ceteris paribus, of supplying informal labour. Being currently unemployed has a stronger marginal effect (14.6 and 3.5 percentage points for men and women, respectively) than having been unemployed in the past ( 8.6 and 1.5 percentage points); this makes sense, since both opportunity cost and the effect on income of engaging in informal labour supply are greater for the currently unemployed than for those unemployed in the past. The effect is not statistically significant for women. However, fear of becoming unemployed in the near future is a significant positive determinant of female, but not male, informal labour supply.

The degree of dissatisfaction with one's relative standing in society, the extent of perceived bureaucracy in government institutions and the perceived waste of tax money significantly increase male, but not female, informal labour supply. Compared to men who consider themselves to be "very advantaged", those who consider themselves to be"very disadvantaged" have an 11 percentage point higher probability of informal labour supply (dissatisfaction is measured on a five-point scale). Haigner et al. (2013) hestitate to interpret these estimations as causal effects, however, since causality could be reversed (i.e. justification bias).

The perceived risk of being audited by the tax authorities has a highly significant negative effect on informal labour supply. Moving one step up on the four-step risk scale decreases the

\footnotetext{
${ }^{44)}$ The points (4) to (7) are taken from Haigner et al. (2013).

${ }^{45)}$ They also ran multinomial logit regressions because they essentially have three, not two, categories of answers: supplying/using informal labour (1), not supplying/using informal labour (0) and no answer (2). However, since only 3.99 per cent of the respondents did not answer, and the results are similar, they present only the probit regressions (excluding individuals who did not answer).

${ }^{46)}$ Of the 2,104 observations, 88 were not used in the regression analysis; these were the "no-replies".
} 
probability of informal labour supply by 8.2 (men) and 3.9 (women) percentage points. For women, their age and whether they have children have small but significant positive effects.

Table 5.3: Marginal effects on informal labor supply (probit regression)

\begin{tabular}{|c|c|c|}
\hline \multirow[b]{3}{*}{ Independent variables } & \multicolumn{2}{|c|}{ Marginal effects } \\
\hline & \multicolumn{2}{|c|}{ Dependent variable: informal labour supply } \\
\hline & Women & Men \\
\hline \multirow[t]{2}{*}{ Age } & 0.006 & 0.001 \\
\hline & {$[0.003]^{* *}$} & [0.006] \\
\hline \multirow[t]{2}{*}{ Age squared } & 0 & 0 \\
\hline & {$[0.000]^{* * *}$} & [0.000] \\
\hline \multirow[t]{2}{*}{ Married } & -0.018 & 0.003 \\
\hline & [0.011] & [0.031] \\
\hline \multirow[t]{2}{*}{ Children } & 0.019 & 0.014 \\
\hline & {$[0.011]^{*}$} & [0.028] \\
\hline \multirow[t]{2}{*}{ Out of labour force } & 0.001 & -0.02 \\
\hline & [0.014] & [0.052] \\
\hline \multirow[t]{2}{*}{ Self-employed } & 0.03 & 0.02 \\
\hline & [0.020] & [0.049] \\
\hline \multirow[t]{2}{*}{ Student } & 0.008 & 0.062 \\
\hline & {$[0.025]$} & {$[0.060]$} \\
\hline \multirow[t]{2}{*}{ Unemployed } & 0.035 & 0.146 \\
\hline & {$[0.019]^{*}$} & {$[0.050]^{* * *}$} \\
\hline \multirow[t]{2}{*}{ Unemployed in past, but not now } & 0.015 & 0.086 \\
\hline & [0.012] & {$[0.033]^{* * *}$} \\
\hline \multirow[t]{2}{*}{ Afraid of becoming unemployed } & 0.031 & 0.059 \\
\hline & {$[0.016]^{* *}$} & {$[0.040]$} \\
\hline \multirow[t]{2}{*}{ Degree of dissatisfaction } & -0.001 & 0.028 \\
\hline & {$[0.005]$} & {$[0.014]^{* *}$} \\
\hline \multirow[t]{2}{*}{ Bureaucracy } & 0.002 & 0.016 \\
\hline & [0.003] & {$[0.007]^{* *}$} \\
\hline \multirow[t]{2}{*}{ Waste of tax money } & 0 & 0.001 \\
\hline & {$[0.000]$} & {$[0.001]^{* *}$} \\
\hline \multirow[t]{2}{*}{ Personal income } & -0.006 & -0.004 \\
\hline & {$[0.005]$} & [0.011] \\
\hline \multirow[t]{2}{*}{ Risk of audit } & -0.039 & -0.082 \\
\hline & {$[0.007]^{* * *}$} & {$[0.015]^{* * *}$} \\
\hline Occupation dummy variables & \multicolumn{2}{|c|}{ Reported in Appendix B of Haigner et al. (2013) } \\
\hline Education dummy variables & \multicolumn{2}{|c|}{ Reported in Appendix B of Haigner et al. (2013) } \\
\hline Pseudo- $\mathrm{R}^{2}$ & 0.215 & 0.173 \\
\hline Predicted probability at $\mathrm{x}$-bar & 0.032 & 0.154 \\
\hline Observations & 1048 & 968 \\
\hline
\end{tabular}

Notes: Standard errors in brackets; * significant at 10 per cent; ** significant at 5 per cent; *** significant at 1 per cent.

Source: Haigner et al. (2013, p. 516) 


\section{(6) Informal labor demand}

As can be seen from table 5.4, the following have no significant effect on the probability of using informal labour: dissatisfaction with one's perceived relative standing in society; current or past unemployment; fear of becoming unemployed in the near future; annoyance at bureaucracy. With regard to perceived waste of tax revenue, Haigner et al. (2013) find a positive and significant effect for women. Thus, while informal labour supply, in particular by men, seems to be driven by unemployment, dissatisfaction, and annoyance, this is not the case for informal labour demand. Rather, informal labour demand is driven by the perceived risk of tax audits and by membership of specific groups of the population (mothers, students and for men - being out of the labour force).

\section{(7) Conclusion}

One of the main findings of Haigner et al. (2013, p. 518) is that being currently unemployed and, to a lesser extent, having been unemployed in the past, increases the probability of supplying informal labour. Clearly, people perceive informal labour supply to be a convenient and - in terms of opportunity costs of time - cheap way of improving income during periods of unemployment. Interestingly, however, many of the unemployed continue to supply informal labour even when they reenter the formal labour market; having been unemployed in the past is found to be another driving force of male informal labour supply. One can understand why some people might choose to continue to supply informal labour; they might have already acquired a set of customers, for example, and informal labour supply could still be a convenient way to improve their income.

In addition, Haigner et al. (2013, p. 518) find that the more men are dissatisfied with their relative standing in society (i.e. the more they feel disadvantaged compared to others) the more likely they are to engage in informal labour supply. This is not the case for women. Also, the higher the perceived degree of bureaucracy in government institutions, the more men are likely to engage in informal labour supply. Haigner et al. (2013) hesitate to interpret these estimations as causal effects, however, since they cannot rule out that causality is reversed (i.e. justification bias). 
Table 5.4: Marginal effects on informal labor demand (probit regression)

\begin{tabular}{|c|c|c|}
\hline \multirow[b]{3}{*}{ Independent variables } & \multicolumn{2}{|c|}{ Marginal effects } \\
\hline & \multicolumn{2}{|c|}{ Dependent variable: informal labour demand } \\
\hline & Women & Men \\
\hline \multirow[t]{2}{*}{ Age } & -0.001 & 0 \\
\hline & {$[0.004]$} & [0.005] \\
\hline \multirow[t]{2}{*}{ Age squared } & 0 & 0 \\
\hline & {$[0.000]$} & [0.000] \\
\hline \multirow[t]{2}{*}{ Married } & -0.006 & 0.025 \\
\hline & {$[0.023]$} & [0.028] \\
\hline \multirow[t]{2}{*}{ Children } & 0.084 & 0.023 \\
\hline & {$[0.023]^{* * *}$} & {$[0.026]$} \\
\hline \multirow[t]{2}{*}{ Out of labour force } & 0.008 & 0.12 \\
\hline & {$[0.028]$} & {$[0.045]^{* * *}$} \\
\hline \multirow[t]{2}{*}{ Self-employed } & 0.04 & 0.083 \\
\hline & {$[0.044]$} & {$[0.040]^{* *}$} \\
\hline \multirow[t]{2}{*}{ Student } & -0.17 & -0.1 \\
\hline & {$[0.083]^{* *}$} & [0.069] \\
\hline \multirow[t]{2}{*}{ Unemployed } & 0.034 & -0.043 \\
\hline & {$[0.043]$} & {$[0.057]$} \\
\hline \multirow[t]{2}{*}{ Unemployed in past, but not now } & 0.034 & 0.007 \\
\hline & {$[0.026]$} & {$[0.031]$} \\
\hline \multirow[t]{2}{*}{ Afraid of becoming unemployed } & 0.016 & -0.03 \\
\hline & {$[0.040]$} & {$[0.041]$} \\
\hline \multirow[t]{2}{*}{ Degree of dissatisfaction } & -0.013 & 0.016 \\
\hline & {$[0.011]$} & [0.013] \\
\hline \multirow[t]{2}{*}{ Bureaucracy } & 0.007 & 0.001 \\
\hline & [0.006] & {$[0.006]$} \\
\hline \multirow[t]{2}{*}{ Waste of tax money } & 0.001 & 0 \\
\hline & {$[0.001]^{*}$} & [0.001] \\
\hline \multirow[t]{2}{*}{ Personal income } & 0.001 & 0.01 \\
\hline & {$[0.009]$} & {$[0.010]$} \\
\hline \multirow[t]{2}{*}{ Risk of audit } & -0.112 & -0.087 \\
\hline & {$[0.037]^{* * *}$} & {$[0.043]^{* *}$} \\
\hline Occupation dummy variables & \multicolumn{2}{|c|}{ Reported in Appendix B of Haigner et al. (2013) } \\
\hline Education dummy variables & \multicolumn{2}{|c|}{ Reported in Appendix B of Haigner et al. (2013) } \\
\hline Pseudo- $\mathrm{R}^{2}$ & 0.093 & 0.097 \\
\hline Predicted probability at x-bar & 0.114 & 0.134 \\
\hline Observations & 1035 & 975 \\
\hline
\end{tabular}

Notes: Standard errors in brackets; * significant at 10 per cent; ** significant at 5 per cent; $* * *$ significant at 1 per cent.

Source: Haigner et al. (2013, p. 517) 


\subsection{The Size of the Shadow Labor Force - World-Wide Aspects}

The following results of the shadow economy labor force are based on the OECD and World Bank database on informal employment in major cities and in rural areas, as well as on other sources mentioned in the footnotes of this chapter and the tables. The values of the shadow economy labor force are calculated in absolute terms, and as a percentage of the official labor force, under the assumption that the shadow economy in rural areas is at least as high as in the cities. This is a conservative assumption, since in reality it is likely to be even larger ${ }^{47)}$. Survey techniques and, for some countries, the MIMIC-method and the method of the discrepancy between the official and actual labor force are used for estimation.

One of the most famous studies is the $\operatorname{OECD}(2009 a, b)$ one with the title "Is informal normal?", which provides worldwide figures. This OECD study ${ }^{48)}$ concludes that in many parts of the world and over the period 1990 to 2007 informal employment is the norm, not the exception,. More than half of all jobs in the non-agricultural sectors of developing countries over 900 million workers - can be considered informal. If agricultural workers in developing countries are included, the estimates size to roughly 2,000 million people. The share of informal employment is also shown in figure 5.4 for Latin America (Part 1) and South East Asia (Part 2). In some regions, including Sub-Saharan Africa and South Asia, over $80 \%$ of nonagricultural jobs are informal. Most informal workers in the developing world are selfemployed and work independently, or owe and manage very small enterprises. According to the OECD study (2009a, b), informal employment is a result of both, people being excluded from official jobs and people voluntarily opting out of formal structures, e.g. in many middle income countries incentives drive individuals and businesses out of the formal sector.

To summarize, this OECD study clearly comes to the conclusion that informal is really the norm or the normal case. 1.8 billion people work in informal jobs, compared to 1.2 billion who benefit from formal contracts and social security protection. Informal economic activity, excluding the agricultural sector, accounts for three quarters of the jobs in Sub-Saharan Africa, for more than two thirds in South and South East Asia, half in Latin America, the Middle

\footnotetext{
${ }^{47)}$ The assumption that the shadow economy labour force is at least as high in rural areas as in major cities, is a very modest one and is supported by Lubell (1991). Some authors (e.g., Lubell (1991), Pozo (1996), and Chickering and Salahdine (1991)) argue that the illicit labour force is nearly twice as high in the countryside as in urban areas. But since no (precise) data exists on this ratio, the assumption of an equal size may be justified arguing that such a calculation provides at least minimal figures.

${ }^{48}$ The following results and figures are taken from the OECD (2009a, b), executive summary.
} 
East and North Africa, and nearly for one quarter in transition countries. If agriculture is included, the informal share of the economy in the above mentioned regions is even higher (e.g. more than $90 \%$ in South Asia). Also, this OECD study comes to the result that more than 700 million informal workers "survive" on less than $\$ 1.25$ a day and some 1.2 billion on less than $\$ 2$ a day. The study also concludes that the share of informal employment tends to increase during economic turmoil. For example, during the Argentine economic crisis (19992002), the countries' "official" economy shrank as by almost one fifth while the share of informal employment expanded from 48 to 52 percent. One can clearly see that even under strong economic growth, the share of non-agricultural employment and, the share of informal employment is strongly rising.

In table 5.5 the share of informal employment in total non-agricultural employment by fiveyear period and by region is presented. From the table one clearly sees that in all regions the share of informal employment has remarkably increased over time. The share of informal employment in South- and Middle-American countries in the period of 1985-1989 was 32.4\% and increased in the period of 2000-2007 to 50.1\%. In 34 Asian countries informal employment rose in the period of 1985-1989 from 55.9\% to 70.2\% from 2000-2007. In the 42 African countries the share of informal employment (in percent of total non-agricultural employment) was $40.3 \%$ from 1985-1989, and increased to $60.5 \%$ in 2000-2007. Table 4.5 clearly demonstrates that there is a very strong positive trend in the share of informal employment (in percent of total non-agricultural employment). This increasing trend is in strong contrast to the overall decreasing trend of the size of the shadow economy measured in value-added. More research is needed here, in order to provide a good explanation. 
Figure 5.4: Informal Employment and GDP in Latin America and Southeast Asia

Part 1: Latin America

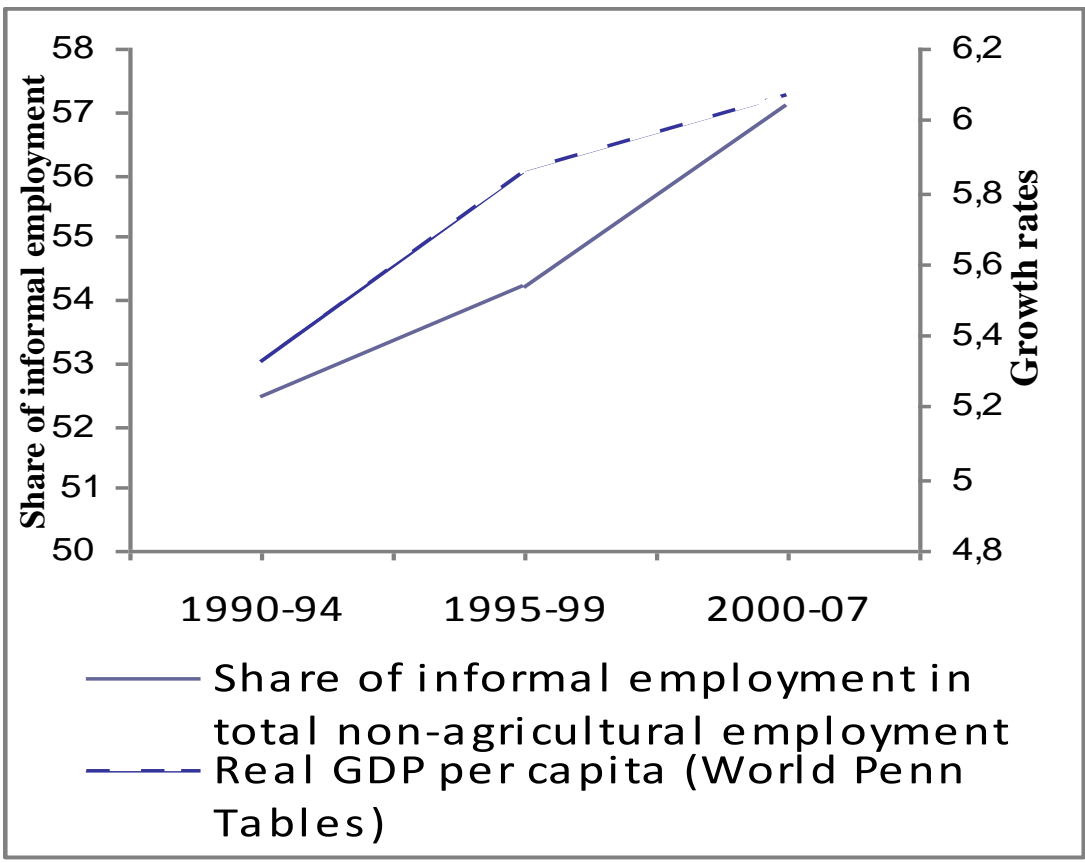

Part 2: $\quad$ Southeast Asia

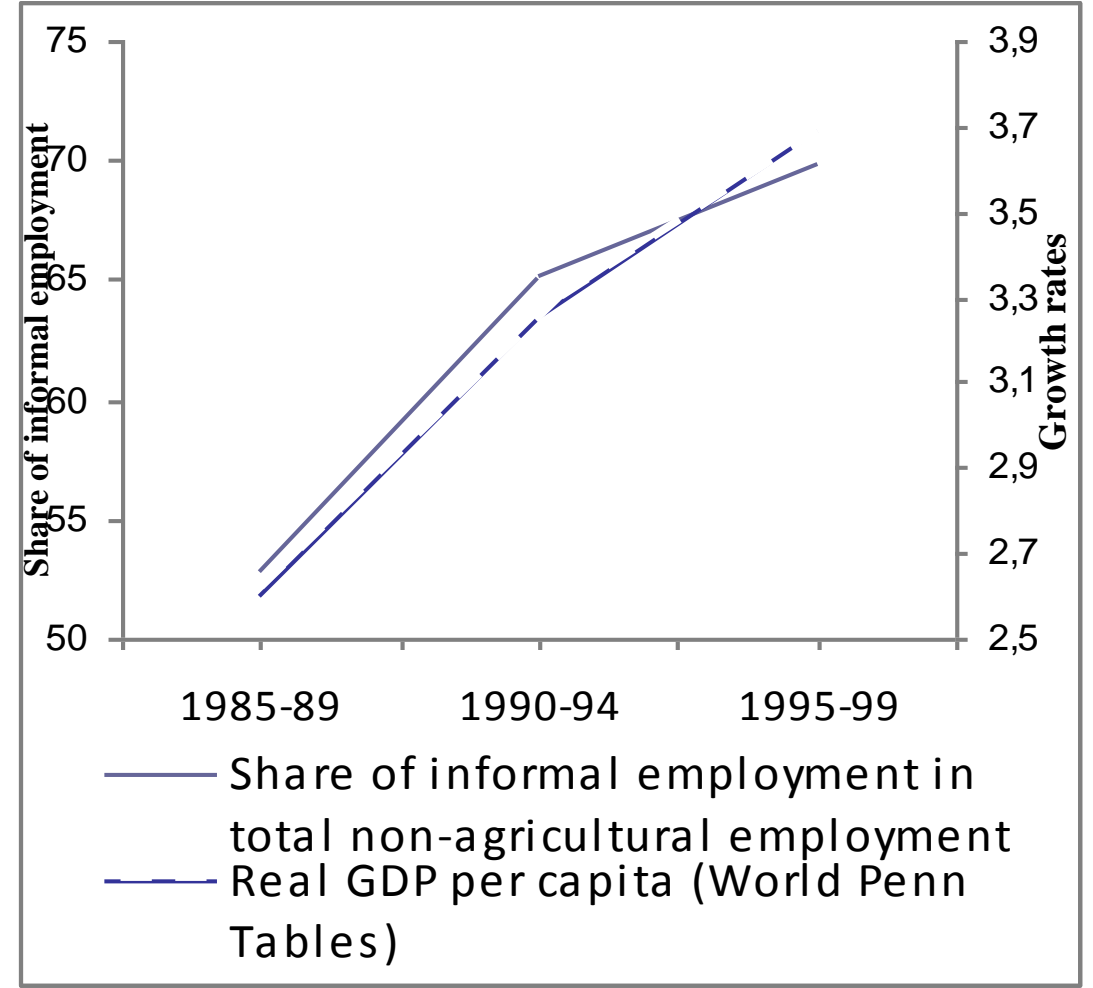

Source: OECD, Is Informal Normal, Paris, 2009a, b. 
Table 5.5: Share of Informal Employment in Total Non-Agricultural Employment by fiveyear period in $\%$

\begin{tabular}{|l|c|c|c|c|}
\hline \multirow{2}{*}{ Region } & \multicolumn{4}{|c|}{$\begin{array}{c}\text { Average Share of Informal Employment in \% of Lo- } \\
\text { cal Non Agricultural Employment over }\end{array}$} \\
\cline { 2 - 5 } & $\mathbf{1 9 8 5 - 8 9}$ & $\mathbf{1 9 9 0 - 9 4}$ & $\mathbf{1 9 9 5 - 9 9}$ & $\mathbf{2 0 0 0 - 0 7}$ \\
\hline $\begin{array}{l}\text { 22 South- and Middle American } \\
\text { Countries }\end{array}$ & 32.4 & 35.4 & 40.3 & 50.1 \\
\hline 34 Asian Countries & 55.9 & 60.4 & 65.4 & 70.2 \\
\hline 42 African Countries & 40.3 & 47.1 & 52.4 & 60.5 \\
\hline 21 Transition Countries & 30.9 & 32.3 & 35.4 & 40.2 \\
\hline
\end{tabular}

Source: OECD 2009a, b, pages 34-35; and Charmes $(2002,2007,2008)$ for the ILO Women and Men in the Informal Economy, 2002.

For the most recent period: Heintz and Chang (2007) for the ILO, and for West Asia: Charmes (2007 and 2008).

\subsection{Shadow labor force and unemployment ${ }^{49)}$}

Although there has been considerable discussion on the size of the shadow labor force, comparatively little attention has been given to the relationship between unemployment and working in the shadow economy. As Tanzi (1999) points out, 'the current literature does not cast much light on these relationships even though the existence of large underground activities would imply that one should look more deeply at what is happening in the labor market' (p. 347). The objective of the paper by Bajada and Schneider (2009) is to examine the extent of participation in the shadow economy by the unemployed. Their paper has investigated the relationship between the unemployment rate and the shadow economy. Previous literature on this topic has suggested that the relationship between these two variables is ambiguous, predominantly because a heterogeneous group of people working in the shadow economy exists and there are also various cyclical forces at work, such that they produce a net effect that is weakly correlated with unemployment. In this paper, they have provided a suggestion for disentangling these cyclical effects, so as to study the component of the shadow economy that is influenced directly by those who are unemployed. They refer to this effect as the 'substitution effect' which typically increases during declining periods of legitimate economic activity (and increasing unemployment). Equipped with this approach for measuring the 'substitution ef-

\footnotetext{
49) This part is taken from Feld and Schneider (2010), pp. 140-141.
} 
fect', they discover that a relationship exists between changes in the unemployment rate and shadow economy activity.

By examining the growth cycle characteristics of the 'substitution effect' component of the shadow economy, Bajada and Schneider (2009) determine that the growth cycles are symmetric (in terms of steepness and deepness) and that changes in the unemployment rate, whether positive or negative, had similar impacts on changes in the substitution effect component. They suggest that the shadow economy is a source of financial support during periods of unemployment for those genuinely wanting to participate in the legitimate economy. Although this does not exclude the possibility that long-term unemployed may also be participating in the shadow economy, it would appear that short-term fluctuations in unemployment directly contribute to short-term fluctuations in the shadow economy.

When Bajada and Schneider consider the various unemployment support programs across 12 OECD countries, there appears to be no real systematic relationship between the generosity of the social security systems and the nature of short-term shadow economic activity by the unemployed. Even the various replacement rates across the OECD countries appear to have little consequence on the rate at which the unemployed take on and cut back shadow economy activity. There is, however, some evidence to suggest that extended duration spells last anywhere between less than three months to approximately nine months.

On the whole Bajada and Schneider argue that dealing with unemployment participation in the shadow economy, a way of correcting the inequity it generates is best handled by more stringent monitoring of those receiving unemployment benefits rather than reducing replacement rates a way of encouraging reintegration into the workforce. A strategy of reducing replacement rates would not only fail to maintain adequate support for those experiencing financial hardship during periods of unemployment, it is likely to have little impact on reducing participation by the unemployed who are willing and able to engage in shadow economy activity. 


\section{SUMMARY AND CONCLUDING REMARKS: PROBLEMS AND OPEN QUESTIONS}

In this survey some of the most recent developments in research on the shadow economy and undeclared work in highly developed OECD, developing and transition countries are shown. The discussion of the recent literature shows that economic opportunities for employees, the overall situation on the labor market, not least unemployment are crucial for an understanding of the dynamics of the shadow economy. Individuals look for ways to improve their economic situation and thus contribute productively to aggregate income of a country. This holds regardless of their being active in the official or the unofficial economy.

First, if I summarize my findings about the methods to estimate the size and development of the shadow economy, I come to the following critical remarks:

The survey method has the disadvantages that quite often only households are considered and firms are, at least partly, left out, that non-responses and/or incorrect responses are given, and that results of the financial volume of "black" hours worked and not of value added are obtained (compare here Feld and Larsen (2005, 2008, 2009), and Kazemier (2006)).

The discrepancy method has the difficulties that quite often a combination of "rough" estimations and unclear assumptions about them is used, the calculation method is often not clear, and the documentation and procedure is often not made public (compare here Thomas (1992)).

The monetary and/or electricity methods result in some very high estimates and only macroestimates are available. Moreover, a breakdown by sector or industry is not possible, and there are great differences to convert millions of $\mathrm{KWh}$ into a value added figure, when using the electricity method (compare Thomas (1992), and Schneider and Williams (2013)).

The MIMIC (latent) method has a number of critical points like: only relative coefficients, no absolute values, are obtained, the estimations are quite often highly sensitive with respect to changes in the data and specifications, there are difficulties to differentiate between the selection of causes and indicators, and the calibration procedure and starting values, which are used, have a great influence on the results (compare Breusch (2005a,b), and Schneider and Williams (2013)).

Second, what type of conclusions can we draw or what have we learnt during 35 years of shadow economy research? 
(1) There is no ideal or dominating method to estimate the size and development of the shadow economy. All methods have serious methodological problems and weaknesses.

(2) If possible, researchers should use several methods to come somewhat closer to the "true" value of the size and development of the shadow economy.

(3) Much more research is needed with respect to the estimation methodology and the empirical results for different countries and periods.

(4) The focus should be now on micro-shadow economy research, and to undertake experiments in order to reach two goals:

(i) a better micro-foundation and

(ii) a better knowledge why people work in the shadow economy, what their motivation is and what they earn.

Third, if I ask what do we know about the shadow economy and work in the shadow, I clearly realize that we have some knowledge about the size and development of the shadow economy and the size and development of the shadow economy labor force. For developing countries, the shadow economy labor force has reached a remarkable size according to OECD $(2009 \mathrm{a}, \mathrm{b})$ estimates, which is, that in most developing countries the shadow economy labor force is higher than the official labor force. What we do not know are the exact motives, why people work in the shadow economy and what is their relation and feeling if a government undertakes reforms in order to bring them back into the official economy. Hence, much more micro studies are needed to obtain a more detailed knowledge about people's motivation to work either the shadow economy and/or in the official one. What is also difficult to explain is that on average the shadow economy measured in value added (in \% of GDP) was shrinking over 1999 to 2007, but the shadow economy labor force was increasing over 1990 to 2007.

Fourth and finally, what questions do remain open?

(1) A common and internationally accepted definition of the shadow economy is still missing. Such a definition or convention is needed in order to make comparisons between the shadow economies of different countries more reliable. 
(2) The link between theory and empirical estimation of the shadow economy is still unsatisfactory; in the best case theory provides us with derived signs of the causal factors, but which are the "core" causal factors is still open and also in which "core" indicators shadow economy activities are reflected.

(3) A satisfactory validation of the empirical results should be developed so that it is easier to judge the empirical results with respect to their plausibility. 


\section{REFERENCES}

Aigner, D., Schneider, F. and D. Ghosh (1988), Me and my shadow: estimating the size of the US hidden economy from time series data, in: Barnett, W.A., Berndt, E.R., White, H. (eds.), Dynamic Econometric Modeling, Cambridge University Press, Cambridge, UK, pp. 224-243.

Ahumada, H., Facundo, A., Canavese A. and P. Canavese (2004), The demand for currency approach and the size of the shadow economy: a critical assessment, Discussion Paper, Delta Ecole Normale Superieure, Paris.

Allingham, M.G. and A. Sandmo (1972), Income Tax Evasion: A Theoretical Analysis, Journal of Public Economics, 1/3, pp. 323-338.

Alm, J., Martinez-Vazquez, J. and F. Schneider (2004), Sizing the problem of the hard-to-tax, Working Paper, Georgia State University, USA.

Alm, J. and B. Torgler (2006), Culture differences and tax morale in the United States and in Europe, Journal of Economic Psychology, 27/2, pp. 224-246.

Amendola, A. and R. Dell'Anno (2010), Institutions and Human Development in the Latin America Shadow Economy, Estudios en Derecho y Gobierno, 3/1, pp. 9-25.

Andreoni, J., Erard B. and J. Feinstein (1998), Tax Compliance, Journal of Economic Literature, 36/4, pp. 818-860.

Bajada, C. and F. Schneider (2009), Unemployment and the Shadow Economy in the OECD, Revue Economique, 60, pp. 1033-1067.

Bartlett, B. (1998), Corruption, the Underground Economy, and Taxation, unpublished manuscript, National Center for Policy Analysis, Washington, D.C.

Belev, B. (2003), The informal economy in the EU Accession Countries: Size, scope, trends and challenges to the process of EU enlargement, Center for Study of Democracy, Sofia.

Bhattacharyya, D.K. (1999), On the economic rationale of estimating the hidden economy, Economic Journal, 109, pp. 348-359.

Blades, D. (1982), The hidden economy and the national accounts, OECD Occasional Studies, pp. $28-44$.

Boeschoten, W.C. and M.M.G. Fase (1984), The Volume of Payments and the Informal Economy in the Netherlands 1965-1982. M. Nijhoff, Dordrecht.

Bollen, K.A. (1989), Structural Equations with Latent Variables, New York (N.Y.), Wiley Publishing Company.

Breusch, T. (2005a), The Canadian underground economy: An examination of Giles and Tedds, Canadian Tax Journal, 53, pp. 367-391.

Breusch, T. (2005b), Estimating the underground economy using MIMIC models, Working Paper. Available under: http://econwpa.wustl.edu/eps/em/papers/0507/0507003.pdf.

Bühn, A. and F. Schneider (2011), Corruption and the shadow economy: like oil and vinegar, like water and fire?, International Tax and Public Finance, LLC: 220-41.

Buehn, A. and F. Schneider (2012), Shadow Economies around the World: Novel Insights, Accepted Knowledge, and New Estimates, International Tax and Public Finance, 19, pp. $139-171$. 
Bühn, A., Karmann, A. and F. Schneider (2009), Shadow economy and do-it-yourself activities: the German case, Journal of Institutional and Theoretical Economics, 165/4, pp.701722 .

Cagan, P. (1958), The demand for currency relative to the total money supply, Journal of Political Economy, 66, pp. 302-328.

Cappiello, M.A. (1986), Proposita di bibliografia ragionata sull'economia sommersa nell'industria (Italia 1970-82), in: A. Bagnasco (ed.): L'altra metà dell'economia, La ricerca internazionale sull'economia informale, Liguori, Naples, pp. 307-345.

Cassar, A. (2001), An index of the underground economy in Malta, Bank of Valletta Review, 23 , pp. 44-62.

Charmes, J. (2002), Informal Sector, Poverty and Gender: A Review of the Empirical Evidence, Paper prepared on behalf of Wiego (Women in Informal Employment: Globalizing and Organizing), OECD and World Bank, Washington and Paris, 2002.

Charmes, J. (2007), Informal Sector Poverty and Gender, A Review of Empirical Evidence, Paper prepared on behalf of Wiego (Women in Formal Employment Globalizing and Organizing), OECD and World Bank, Washington and Paris, 2007.

Charmes, J. (2008), Informal Sector Poverty and Gender, A Review of Empirical Evidence, Paper prepared on behalf of Wiego (Women in Formal Employment Globalizing and Organizing), OECD and World Bank, Washington and Paris 2008.

Chickering, L.A. and M. Salahdine (eds.) (1991), The Silent Revolution - The Informal Sector in Five Asian and near Eastern Countries, An International Center for Economic Growth Publication (ICS Press), San Francisco.

Clotefelter, C.T. (1983), Tax evasion and tax rates: an analysis of individual returns, Review of Economic Statistics, 65, pp. 363-373.

Contini, B. (1981), Labor market segmentation and the development of the parallel economy: the Italian experience, Oxford Economic Papers, 33, pp. 401-412.

Cziraky, D. (2004), LISREL 8.54: A program for structural equation modelling with latent variables, Journal of Applied Econometrics, 19, pp. 135-141.

Dallago, B. (1990), The Irregular Economy: The "Underground Economy" and the "Black Labour Market", Dartmouth Publishing, UK.

De la Roca, J., Hernandez, M., Robles, M., Torero M. and M. Webber (2002), Informal Sector Study for Jamaica, Group of Analysis for Development, Inter-American Development Bank, Washington D.C.

Dell'Anno, R. (2003), Estimating the shadow economy in Italy: A structural equation approach, Working Paper 2003-7, Department of Economics, University of Aarhus, Aarhus, Denkmark.

Dell'Anno R. (2007), The Shadow Economy in Portugal: An Analysis with the MIMIC Approach, Journal of Applied Economics, 10, pp. 253-277.

Del'Anno, R. and F. Schneider, (2004), The shadow economy of Italy and other OECD countries: what do we know?, Discussion Paper, Department of Economics, University of Linz, Linz, Austria. 
Dell'Anno, R. and F. Schneider (2009), A complex approach to estimate shadow economy: the structural equation modelling, in M. Faggnini and T. Looks (eds), Coping with the Complexity of Economics, Springer, Berlin, pp. 110-30.

Dell'Anno R., Gomez-Antonio, M. and A. Alanon Pardo (2007), Shadow Economy in three different Mediterranean Countries: France, Spain and Greece. A MIMIC Approach, Empirical Economics, 33, pp. 51-84.

Del Boca, D. (1981), Parallel economy and allocation of time, Micros (Quarterly Journal of Microeconomics), 4, pp. 13-18.

Del Boca, D. and F. Forte (1982), Recent empirical surveys and theoretical interpretations of the parallel economy in Italy, in: Tanzi, V. (ed.), The Underground Economy in the United States and Abroad, Lexington Books, Lexington, MA, pp. 160-178.

Dreher, A. and F. Schneider (2009), Corruption and the Shadow Economy: An Empirical Analysis, Public Choice, 144/2, pp. 215-277.

Dreher, A., Kotsogiannis, C. and S. McCorriston (2009), How Do Institutions Affect Corruption and the Shadow Economy?, International Tax and Public Finance, 16/4, pp.773-796.

Enste, D. and F. Schneider (2006), Umfang und Entwicklung der Schattenwirtschaft in 145 Ländern, in: F. Schneider and D. Enste (eds.), Jahrbuch Schattenwirtschaft 2006/07. Zum Spannungsfeld von Poltik und Ökonomie, LIT Verlag, Berlin, pp. 55-80.

European Commission (2007), Stepping up the fight against undeclared work, COM (2007) 628 final, European Commission, Brussels.

Feige, E.L. (1986), A re-examination of the underground economy in the United States, IMF Staff Papers, 33, pp. 768-781.

Feige, E.L. (ed.) (1989), The Underground Economies. Tax Evasion and Information Distortion, Cambridge University Press, Cambridge.

Feige, E.L. (1994), The underground economy and the currency enigma, Supplement to Public Finance/Finances Publiques, 49, pp. 119-136.

Feige, E.L. (1996), Overseas holdings of U.S. currency and the underground economy. In: Pozo, S. (Ed.), Exploring the Underground Economy. W.E. Upjohn Institute for Employment Research, Kalamazoo, MI, pp. 5-62.

Feld, L.P. and B.S. Frey (2007), Tax Compliance as the Result of a Psychological Tax Contract: The Role of Incentives and Responsive Regulation, Law and Policy, 29/1, pp. 102120.

Feld, L. P. and C. Larsen (2005), Black Activities in Germany in 2001 and 2004: A Comparison Based on Survey Data, Study no.12, Copenhagen: Rockwool Foundation Research Unit.

Feld, L. P. and C. Larsen (2008), "Black" activities low in Germany in 2006, News from the Rockwool Foundation Research Unit, March, pp. 1-12.

Feld, L. P. and C. Larsen (2009), Undeclared Work in Germany 2001-2007 - Impact of Deterrence, Tax Policy, and Social Norms: An Analysis Based on Survey Data, Springer, Berlin.

Feld, L. P. and F. Schneider (2010), Survey on the shadow economy and undeclared earnings in OECD countries, German Economic Review, 11/2, pp. 109-49. 
Fleming, M.H., Roman, J. and G. Farrel (2000), The shadow economy, Journal of International Affairs, 53, pp. 64-89.

Folmer, H. and A. Karmann (1992), The permanent income hypothesis revisited - a dynamic LISREL approach, Methods of Operations Research, 64/3, pp. 355-359.

Franz, A. (1983), Wie groß ist die „schwarze“ Wirtschaft? Mitteilungsblatt der Österreichischen Statistischen Gesellschaft, 49, pp. 1-6.

Frey, B.S. and W. Pommerehne (1984), The hidden economy: State and prospect for measurement, Review of Income and Wealth, 30/1, pp. 1-23.

Frey, B.S. and H. Weck (1983a), Bureaucracy and the shadow economy: a macro-approach, in: Hanusch, H. (ed.), Anatomy of Government Deficiencies, Springer, Berlin, pp. 89-109.

Frey, B.S. and H. Weck (1983b), Estimating the shadow economy: a "naïve" approach, $O x$ ford Economic Papers, 35, pp. 23-44.

Frey, B.S. and H. Weck-Hannemann (1984), The hidden economy as an "unobserved" variable, European Economic Review, 26, pp. 33-53.

Frey, B.S., Weck, H. and W.W. Pommerehne (1982), Has the shadow economy grown in Germany? An exploratory study, Weltwirtschaftliches Archiv, 118, pp. 499-524.

Frey, L. (1972), Il lavoro a domicilio in Lombardia, Giunta Regionale Lombarda, Assessorato al Lavoro, Milan.

Frey, L. (1975), Il potenziale di lavoro in Italia, Documenti ISVET, no. 50.

Frey, L. (1978), Il lavoro nero nel 1977 in Italia, Tendenze della occupazione, no. 6.

Frey, L. (1980), Introduzione all'analisi economica del lavoro minorile, Economia del Lavoro, no. 1-2, pp. 5-16.

Friedman, E., Johnson, S., Kaufmann, D. and P. Zoido-Lobatón (2000), Dodging the Grabbing Hand: The Determinants of Unofficial Activity in 69 Countries, Journal of Public Economics, 76/4, pp. 459-493.

Garcia, G. (1978), The currency ratio and the subterranean economy, Financial Analysts Journal, 69, pp. 64-66.

Gerxhani, K. (2003), The informal sector in developed and less-developed countries: A literature survey, Public Choice, 114/3-4, pp. 295-318.

Giles, D.E.A. (1997a), Causality between the measured and underground economies in New Zealand, Applied Economics Letters, 4, pp. 63-67.

Giles, D.E.A. (1997b), Testing the asymmetry in the measured and underground business cycles in New Zealand, Economic Record, 71, pp. 225-232.

Giles, D.E.A. (1999a), Measuring the Hidden Economy: Implications for Econometric Modelling, Economic Journal, 109/3, pp. 370-380.

Giles, D.E.A. (1999b), Modeling the hidden economy in the tax-gap in New Zealand, Empirical Economics, 24, pp. 621-640.

Giles, D.E.A. (1999c), The rise and fall of the New Zealand underground economy: are the reasons symmetric?, Applied Economics Letters, 6, pp. 185-189.

Giles, D.E.A. and L.M. Tedds (2002), Taxes and the Canadian underground economy, Canadian Tax Paper, vol. 106. Canadian Tax Foundation, Toronto. 
Giles, D.E.A., Tedds, L.M. and W. Gugsa (2002), The Canadian underground and measured economies, Applied Economics, 34, pp. 2347-2352.

Greenidge, K., Holder, C. and S. Mayers (2005), Estimating the Size of the Underground Economy in Barbados, paper presented at the $26^{\text {th }}$ Annual Review Seminar, Research Department, Central Bank of Barbados, July 26-29, 2005.

Gutmann, P.M. (1977), The subterranean economy, Financial Analysts Journal, 34/1, pp. 2427.

Haigner, S., Jenewein, S., Schneider F. and F. Wakolbinger (2013), Driving Forces of Informal Labour Supply and Demand in Germany, International Labour Review, 152/3-4, pp. 507-524.

Hazans, M. (2011), Informal Workers across Europe, Evidence from 30 Countries, Discussion Paper and Background Paper, Worldbank, P112988, University of Latvia.

Heintz, E. and G.B. Chang (2007), Report of Informal Employment for the ILO, ILO Geneva.

Helberger, C. and H. Knepel (1988), How big is the shadow economy? A re-analysis of the unobserved-variable approach of B.S. Frey and H.Weck-Hannemann, European Economic Review, 32/4, pp. 965-976.

Hill, R. and M. Kabir (1996), Tax rates, the tax mix, and the growth of the underground economy in Canada: what can we infer?, Canadian Tax Journal/Revue Fiscale Canadienne, 44, pp. $1552-1583$.

Hvidtfeldt, C., Jensen, B. and C. Larsen (2011), Undeclared work and the Danes, Universitiy Press of Southern Denmark, June 2010, English summary reported in: Rockwool Foundation Research Unit, News, March 2011, Copenhagen, Denmark.

IfD Allensbach (1975), Studie im Auftrag der Kommission für Wirtschaftlichen und Sozialen Wandel, Bodensee: Allensbach.

IRS (1979), Estimates of Income Unreported on Individual Tax Reform, Internal Revenue Service, U.S. Department of the Treasury, Washington, DC.

IRS (1983), Income Tax Compliance Research: Estimates for 1973-81, Internal Revenue Service, U.S. Department of the Treasury, Washington, DC.

Isachsen, A.J. and S. Strøm (1985), The Size and Growth of the Hidden Economy in Norway, Review of Income and Wealth, 31/1, pp. 21-38.

Isachsen, A.J., Klovland, J. and S. Strom (1982), The hidden economy in Norway, in: Tanzi, V. (ed.), The Underground Economy in the United States and Abroad, DC Heath, Lexington Books, Lexington, MA, pp. 209-231.

Jöreskog, K.G. and D. Sörbom (2001), LISREL 8: User's Reference Guide, Lincolnwood: Scientific Software International.

Johnson, S., Kaufmann, D. and A. Shleifer (1997), The unofficial economy in transition, Brookings Papers on Economic Activity, Fall, Washington D.C.

Johnson, S., Kaufmann, D. and P. Zoido-Lobatón (1998a), Regulatory discretion and the unofficial economy, The American Economic Review, 88/2, pp. 387-392.

Johnson, S., Kaufmann D. and P. Zoido-Lobatón (1998b), Corruption, Public Finances and the Unofficial Economy, World Bank Policy Research Working Paper Series No. 2169, The World Bank, Washington, D.C. 
Kanniainen, V., Pääkönen J. and F. Schneider (2004), Fiscal and Ethical Determinants of Shadow Economy: Theorey and Evidence, Discussion Paper, Department of Economics, Johannes Kepler University of Linz, Linz, Austria.

Karmann, A. (1986), Monetäre Ansätze zur Erfassung der Schattenwirtschaft: Ein Vergleich verschiedener Messansätze, Kredit und Kapitel, 19, pp. 233-247.

Karmann, A. (1990), Schattenwirtschaft und ihre Ursachen: Eine empirische Analyse zur Schwarzwirtschaft und Selbstversorgung in der Bundesrepublik Deutschland, Zeitschrift für Wirtschafts- und Sozialwissenschaften (ZWS), 110, pp. 185-206.

Kaufmann, D. and A. Kaliberda (1996), Integrating the unofficial economy into the dynamics of post socialist economies: a framework of analyses and evidence, in: Kaminski, B. (ed.), Economic Transition in Russia and the New States of Eurasia. M.E. Sharpe, London, pp. 81-120.

Kazemier, B. (2006), Monitoring the underground economy: a survey of methods and estimates, in: Schneider, F. and D. Enste (eds.), Jahrbuch Schattenwirtschaft 2006/07. Zum Spannungsfeld von Politik und Ökonomie, Berlin: LIT Verlag, pp. 11-53.

Kirchgässner, G. (1983), Size and development of the West German shadow economy, 19551980, Zeitschrift für die Gesamte Staatswissenschaft, 139, pp. 197-214.

Kirchgässner, G. (1984), Verfahren zur Erfassung des in der Schattenwirtschaft erarbeiteten Sozialprodukts, Allgemeines Statistisches Archiv, 68, pp. 378-405.

Kirchler, E. (2007), The Economic Psychology of Tax Behaviour, Cambridge (UK) University Press, Cambridge.

Klovland, J. (1984), Tax evasion and the demand for currency in Norway and Sweden: is there a hidden relationship?, Scandinavian Journal of Economics, 86, pp. 423-439.

Kucera, D. and L. Roncolato (2008), Informal Employment: Two Contested Policy Issues, International Labor Review, 147/3, pp. 321-348.

Lackó, M. (1996), Hidden economy in East-European countries in international comparison, Working paper, International Institute for Applied Systems Analysis (IIASA), Laxenburg.

Lackó, M. (1998), The Hidden Economies of Visegrad Countries in International Comparison: A Household Electricity Approach, in: Halpern, L. and Ch. Wyplosz (eds.), Hungary: Towards a Market Economy, Cambridge (Mass.), Cambridge University Press.

Lackó, M. (1999), Electricity Intensity and the Unrecorded Economy in Post-Socialist Countries, in: Feige, E. and K. Ott (eds.), Underground Economies in Transition, Ashgate Publishing Company.

Lackó, M. (2000a), Do Power Consumption Data Tell the Story? Electricity Intensity and Hidden Economy in Post-Socialist Countries, in: Maskin, E. and A. Simonovits (eds.), Planning, Shortage and Transformation: Essays in Honor of Janos Kornai, Cambridge (Mass.), The MIT Press.

Lackó, M. (2000b), Hidden Economy - an Unknown Quantity? Comparative Analysis of Hidden Economies in Transition Economies, 1989-95, Economics of Transition, 8/1, pp. 117-149.

Langfeldt, E. (1984), The unobserved economy in the Federal Republic of Germany, in: Feige, E.L. (ed.), The Unobserved Economy, Cambridge University Press, Cambridge, UK, pp. 236-260. 
Lemieux. T., Fortin, B. and P. Fréchette (1994), The Effect of Taxes on Labor Suppy in the Underground Economy, American Economic Review, 84/3, pp. 231-254.

Lippert, O. and M. Walker (eds.) (1997), The Underground Economy: Global Evidences of its Size and Impact, The Frazer Institute, Vancouver, B.C.

Lizzeri, C. (1979), Mezzogiorno in Controluce. Enel, Naples.

Loayza, N. V. (1996), The economics of the informal sector: a simple model and some empirical evidence from Latin America, Carnegie-Rochester Conference Series on Public Policy, 45, pp. 129-162.

Long, J.S. (1983a), Confirmatory Factor Analysis, Sage Publishing Company, Beverly Hills (CA).

Long, J.S. (1983b), Covariance Structure Models: An Introduction to LISREL, Sage Publishing Company, Beverly Hills (CA).

Losby, J.L., Else, J.F., Kingslow, M.E., Edgcomb, E.L., Malm, E.T. and V. Kao (2002), Informal Economy Literature Review, The Aspen Institute, Microenterprise Fund for Innovation, Effectiveness, Learning and Dissemination, Washingtion D.C., and ISED Consulting and Research, Newark DE.

Lubell, H. (1991), The Informal Sector in the 1980's and 1990's, OECD, Paris.

MacAfee, K. (1980), A glimpse of the hidden economy in the national accounts, Economic Trends, 136, pp. 81-87.

Mogensen, G. V. (1985), Sort Arbejde i Danmark, Institut for Nationalokonomi, Copenhagen.

Mogensen, G.V., Kvist, H.K., Kfrmendi, E. and S. Pedersen (1995), The Shadow Economy in Denmark 1994: Measurement and Results, Study no. 3, The Rockwool Foundation Research Unit, Copenhagen.

Mootoo, L., Sookram S. and P.K. Watson (2002), Size and Structure of the Hidden Economy in the Caribbean, Economic Measurement Unit, Department of Economics, University of the West Indies, St. Augustine, Trinidad \& Tobago.

Morris, B. (1993), Editorial statement, International Economic Insides, vol. IV. International Statistical Yearbook, Budapest.

O'Higgins, M. (1989), Assessing the underground economy in the United Kingdom, in: Feige, E.L. (ed.), The Underground Economies: Tax Evasion and Information Distortion, Cambridge University Press, Cambridge, UK, pp. 175-195.

O'Neill, D.M. (1983), Growth of the underground economy 1950-81: some evidence from the current population survey, Study for the Joint Economic Committee, U.S. Congress Joint Committee Print, U.S. Gov. Printing Office, Washington, DC, pp. 98-122.

OECD (2009a), Is Informal Normal? Towards More and Better Jobs, OECD, Paris.

OECD (2009b), Policy Round Tables, Competition Policy and the Informal Economy, OECD, Paris.

Olssen, U.H., Troye, S.V. and R.D. Howell (1999), Theoretic fit and empirical fit: The performance of Maximum Likelihood versus Generalized Least Squares estimation in Structural Equations Models, Multivariate Behavioral Research, 34/1, pp. 31-58. 
Olssen, U.H., Foss, T., Troye, S.V. and R.D. Howell (2000), The performance of ML, GLS, and WLS estimation in structural equation modeling under conditions of misspecification and nonnormality, Structural Equation Modeling, 7, pp. 557-595.

Park, T. (1979), Reconciliation Between Personal Income and Taxable Income, Bureau of Economic Analysis, Washington, DC, pp. 1947-1977.

Pedersen, S. (2003), The Shadow Economy in Germany, Great Britain and Scandinavia: A Measurement Based on Questionnaire Service, Study No. 10, The Rockwoll Foundation Research Unit, Copenhagen.

Petersen, H.G. (1982), Size of the public sector, economic growth and the informal economy: development trends in the Federal Republic of Germany, Review of Income and Wealth, 28, pp. 191-215.

Pickhardt, M. and J. Sardà Pons (2006), Size and scope of the underground economy in Germany, Applied Economics, 38(4), pp. 1707-13.

Pissarides, C. and G. Weber (1989), An expenditure-based estimate of Britain's black economy, Journal of Public Economics, 39, pp. 17-32.

Pommerehne, W.W. and F. Schneider (1985), The decline of productivity growth and the rise of the shadow economy in the U.S., Working Paper 85-9, University of Aarhus.

Portes, A. (1996), The informal economy, in: Pozo, S. (ed.), Exploring the Underground Economy, W.E. Upjohn Institute for Employment Research, Kalamazoo, pp. 147-165.

Posner, E.A. (2000), Law and Social Norms, Harvard University Press, Cambridge.

Pozo, S. (ed.) (1996), Exploring the Underground Economy: Studies of Illegal and Unreported Activity, Michigan: W.E. Upjohn, Institute for Employment Research.

Renooy, P., Ivarsson, S., van der Wusten-Gritsai, O. and E. Meijer (2004), Undeclared Work in an Enlarged Union - An Analysis of Undeclared Work: An In-Depth Study of Specific Items, European Commission, Brussels.

Rogoff, K. (1998), Blessing or curse? Foreign and underground demand for euro notes, Economic Policy: The European Forum, 26, pp. 261-304.

Schneider, F. (1986), Estimating the size of the Danish shadow economy using the currency demand approach: an attempt, The Scandinavian Journal of Economics, 88, pp. 643-668.

Schneider, F. (1994a), Measuring the size and development of the shadow economy. Can the causes be found and the obstacles be overcome?, in: Brandstaetter, H. and W. Güth (eds.): Essays on Economic Psychology, Berlin, Heidelberg, Springer Publishing Company, pp. 193-212.

Schneider, F. (1994b), Can the shadow economy be reduced through major tax reforms? An empirical investigation for Austria, Supplement to Public Financel Finances Publiques, 49, pp. 137-152.

Schneider, F. (1997), The shadow economies of Western Europe, Journal of the Institute of Economic Affairs, 17/3, pp. 42-48.

Schneider, F. (1998), Further empirical results of the size of the shadow economy of 17 OECD-countries over time, Paper to be presented at the 54. Congress of the IIPF Cordowa, Argentina and discussion paper, Department of Economics, University of Linz, Linz, Austria. 
Schneider, F. (2003), The shadow economy, in: Rowley, C.K. and F. Schneider (eds.), Encyclopedia of Public Choice, Kluwer Academic Publishers, Dordrecht.

Schneider, F. (2005), Shadow economies around the world: what do we really know?, European Journal of Political Economy, 21(4), pp. 598-642.

Schneider, F. (2007), Shadow Economies and Corruption All Over the World: New Estimates for 145 Countries, Economics, 2007-9, July.

Schneider, F. (2010), The Influence of Public Institutions on the Shadow Economy: An Empirical Investigation for OECD Countries, European Journal of Law and Economics, 6/3, pp.441-468.

Schneider, F. (ed.) (2011), Handbook on the Shadow Economy, Edward Elgar, Cheltenham.

Schneider, F. and A. Buehn (2013), Shadow Economies in Highly Developed OECDCountries: What are the Driving Forces?, Discussion Paper, Department of Economics, University of Linz, Linz, Austria, June 2013.

Schneider, F. and D. Enste (2000), Shadow economies: Size, causes, and consequences, The Journal of Economic Literature, 38/1, pp. 77-114.

Schneider, F. and D. Enste (2002), The Shadow Economy: Theoretical Approaches, Empirical Studies, and Political Implications, Cambridge University Press, Cambridge (UK).

Schneider, F. and C.C. Willams (2013), The Shadow Economy, IEA, London.

Schneider, F., Buehn, A. and C.E. Montenegro (2010), New Estimates for the Shadow Economies all over the World, International Economic Journal, 24/4, pp. 443-461.

Simon, C.B. and A.G. Witte (1982), Beating the System: The Underground Economy, Urban House, Boston, MA.

Smith, J.D. (1985), Market motives in the informal economy, in: Gaertner, W. and A. Wenig (eds.), The Economics of the Shadow Economy, Springer, Heidelberg, pp. 161-177.

Smith, P. (1994), Assessing the size of the underground economy: the Canadian statistical perspectives, Canadian Economic Observer, 11, pp. 16-33.

Stapleton, D.C. (1978), Analyzing political participation data with a MIMIC Model, Sociological Methodology, 15/1, pp. 52-74.

Swaminathan, H. and J. Algina (1978), Scale freeness in factor analysis, Psychometrika, 43, pp. 581-583.

Tanzi, V. (1980), The underground economy in the United States: estimates and implications, Banca Nazionale del Lavoro, 135, pp. 427-453.

Tanzi, V. (ed.) (1982a), The Underground Economy in the United States and Abroad, Lexington Books, Lexington, MA.

Tanzi, V. (1982b), A second (and more skeptical) look at the underground economy in the United States, in: Tanzi, V. (ed.), The Underground Economy in the United States and Abroad, Lexington Books, Lexington, MA, pp. 38-56.

Tanzi, V. (1983), The underground economy in the United States: annual estimates, 19301980, IMF Staff Papers, 30, pp. 283-305.

Tanzi, V. (1986), The underground economy in the United States: reply to comments by Feige, Thomas, and Zilberfarb, IMF Staff Papers, 33, pp. 799-811. 
Tanzi, V. (1999), Uses and Abuses of Estimates of the Underground Economy, Economic Journal, 109/3, pp. 338-347.

Teobaldelli, D. (2011), Federalism and the Shadow Economy, Public Choice, 146/3, pp. 269269.

Teobaldelli, D. and F. Schneider (2012), Beyond the veil of ignorance: The influence of direct democracy on the shadow economy, CESifo Working Paper MO3749, University of Munich, Munich.

Thomas, J.J. (1986), The underground economy in the United States: comment on Tanzi, IMF Staff Papers, 33, pp. 782-789.

Thomas, J. J. (1992), Informal Economic Activity, LSE, Handbooks in Economics, Harvester Wheatsheaf, London.

Thomas, J.J. (1999), Quantifying the Black Economy: 'Measurement Without Theory' Yet Again?, Economic Journal, 109, pp. 381-389.

Torgler, B. and F. Schneider (2009), The Impact of Tax Morale and Institutional Quality on the Shadow Economy, Journal of Economic Psychology, 30/3, pp. 228-245.

Van Eck, R. and B. Kazemier (1988), Features of the hidden economy in the Netherlands, Review of Income and Wealth, 34/3, pp. 251-73.

Vuletin, G. (2008), Measuring the Informal Economy in Latin America and the Caribbean, International Monetary Fund, IMW Working Paper WP/08/102, Washington D.C.

Weck-Hannemann, H. (1983), Schattenwirtschaft: Eine Möglichkeit zur Einschränkung der öffentlichen Verwaltung? Eine ökonomische Analyze, Bern-Frankfurt.

Williams, C.C. (2007), Tackling undeclared work in Europe: Lessons from a study of Ukraine, European Journal of Industrial Relations, 13/2, pp. 219-237.

Williams, C.C. (2009), Formal and informal employment in Europe: Beyond dualistic representations, European Urban and Regional Studies, 16/2, pp. 147-159.

Williams, C.C. (2013), Evaluating cross-national variations in the extent and nature of informal employment in the European Union, Industrial Relations Journal, 44/5-6, pp. 479494.

Williams, C.C. and M.A. Lansky (2013), Informal employment in developed and developing economies: Perspectives and policy responses, International Labour Review, 152/3-4, pp. $355-380$.

Williams, C.C. and P. Rodgers (2013), The role of informal economies in the post-Soviet world: The end of transition?, Routledge Publishing Company, London.

Williams, C.C. and J. Windebank (1995), Black market work in the European Community: peripheral work for peripheral localities?, International Journal of Urban and Regional Research, 19, pp. 23-39.

Williams, C.C. and J. Windebank (1998), Informal Employment in the Advanced Economies: Implication for Work and Welfare, Routledge Publishing Company, London.

Witte, A.D. (1987), The nature and extend of unreported activity: a survey concentrating on a recent US research, in: Alessandrini, S. and B. Dallago (eds.), The Unofficial Economy: Consequences and Perspectives in Different Economic Systems, Gower, Aldershot. 
Zilberfarb, B.-Z. (1986), Estimates of the underground economy in the United States, 193080, IMF Staff Papers, 33, pp. 790-798. 